\title{
Drosophila Neprilysin 1 Rescues Memory Deficits Caused by Amyloid- $\beta$ Peptide
}

\author{
Oriane Turrel, (alérie Goguel,* and ๑Thomas Preat ${ }^{\star}$ \\ Genes and Dynamics of Memory Systems, Brain Plasticity Unit, Centre National de la Recherche Scientifique, ESPCI Paris, PSL Research University, 75005 \\ Paris, France
}

Neprilysins are Type II metalloproteinases known to degrade and inactivate a number of small peptides, in particular the mammalian amyloid- $\beta$ peptide (A $\beta$ ). In Drosophila, several neprilysins expressed in the brain are required for middle-term (MTM) and long-term memory (LTM) in the dorsal paired medial (DPM) neurons, a pair of large neurons that broadly innervate the mushroom bodies (MB), the center of olfactory memory. These data indicate that one or several peptides need to be degraded for MTM and LTM. We have previously shown that the fly amyloid precursor protein (APPL) is required for memory in the MB. We show here that APPL is also required in adult DPM neurons for MTM and LTM formation. This finding prompted us to search for an interaction between neprilysins and Drosophila A $\beta$ $(\mathrm{dA} \beta)$, a cleavage product of APPL. To find out whether $\mathrm{dA} \beta$ was a neprilysin's target, we used inducible drivers to modulate neprilysin 1 (Nep1) and dA $\beta$ expression in adult DPM neurons. Experiments were conducted either in both sexes or in females. We show that Nep1 inhibition makes $\mathrm{dA} \beta$ expression detrimental to both MTM and LTM. Conversely, memory deficits displayed by dA $\beta$-expressing flies are rescued by Nep1 overexpression. Consistent with behavioral data, biochemical analyses confirmed that Nep $1 \mathrm{degrades} \mathrm{dA} \beta$. Together, our findings establish that Nep1 and $\mathrm{dA} \beta$ expressed in DPM neurons are functionally linked for memory processes, suggesting that $\mathrm{dA} \beta$ is a physiological target for Nep1.

Key words: amyloid peptide; dorsal paired medial neurons; Drosophila; learning and memory; neprilysin; olfactory conditioning

\section{Significance Statement}

Neprilysins are endopeptidases known to degrade a number of small peptides and in particular the amyloid peptide. We previously showed that all four neprilysins expressed in the Drosophila brain are involved in specific phases of olfactory memory. Here we show that an increase in the level of the neprilysin 1 peptidase overcomes memory deficits induced by amyloid peptide in young flies. Together, the data reveal a functional interaction between neprilysin 1 and amyloid peptide, suggesting that neprilysin 1 degrades amyloid peptide. These findings raise the possibility that, under nonpathological conditions, mammalian neprilysins degrade amyloid peptide to ensure memory formation.

\section{Introduction}

Alzheimer's disease (AD) is a progressive neurodegenerative disorder that first manifests as a memory decline. Its dominant histological hallmark is the accumulation of amyloid- $\beta$ peptides $(\mathrm{A} \beta)$ produced by the processing of the amyloid precursor pro-

Received June 13, 2017; revised Sept. 7, 2017; accepted Sept. 15, 2017.

Author contributions: V.G. and T.P. designed research; 0.T. and V.G. performed research; 0.T., V.G., and T.P. analyzed data; 0.T. and V.G. wrote the paper.

T.P. was supported by Fondation pour la Recherche Médicale DEQ20140329540. We thank Aurélie Lampin-SaintAmaux, Honorine Lucchi, and Noé Testa for technical help; and all the members of our laboratory for valuable discussions and for critically reading this manuscript.

The authors declare no competing financial interests.

*V.G. and T.P. contributed equally to this work.

Correspondence should be addressed to either Dr. Valérie Goguel or Dr. Thomas Preat, Genes and Dynamics of

Memory Systems, Brain Plasticity Unit, Centre National de la Recherche Scientifique, ESPCI Paris, PSL Research University, 10 rue Vauquelin, 75005 Paris, France. E-mail: valerie.goguel@espci.fr or thomas.preat@espci.fr.

DOI:10.1523/JNEUROSCI.1634-17.2017

Copyright $\odot 2017$ the authors $\quad 0270-6474 / 17 / 3710334-12 \$ 15.00 / 0$ tein (APP) following the amyloidogenic pathway (Turner et al., 2003). This proteolytic pathway is initiated by the rate-limiting enzyme $\beta$-secretase (BACE) (Cole and Vassar, 2007). As for any protein, the $\mathrm{A} \beta$ steady-state level results from a balance between its synthesis and its degradation. Neprilysins (Nep), known as membrane metallo-endopeptidases, have been highlighted as the main enzyme for $A \beta$ degradation in humans (Turner, 2003; Nalivaeva et al., 2012). It has been shown that Nep level and activity decrease during $\mathrm{AD}$ progression, suggesting that a reduction in $\mathrm{A} \beta$ degradation may contribute to the development of the disease (Yasojima et al., 2001; Caccamo et al., 2005; Wang et al., 2010; Zhou et al., 2013). In mouse models of AD, an increase in Nep activity ameliorates the memory deficits observed (Poirier et al., 2006; Spencer et al., 2008; Park et al., 2013), whereas Nep deficiency worsens them (Hüttenrauch et al., 2015).

Drosophila melanogaster is a model system well suited to analyzing the influence of the APP pathway on memory. Impor- 
tantly, the fly genome contains homologs of $75 \%$ of human disease-related genes (Reiter et al., 2001), and molecules and mechanisms underlying memory processes are conserved from flies to mammals. Although relatively simple, the fly brain is highly organized and sustains complex forms of learning and memory. The mushroom bodies (MB) constitute the central integrative brain structure for olfactory associative memory. They are composed of $\sim 4000$ neurons, the Kenyon cells (KC), classified into three subtypes whose axons form five lobes: two vertical ( $\alpha$ and $\left.\alpha^{\prime}\right)$ and three me$\operatorname{dial}\left(\beta, \beta^{\prime}\right.$, and $\left.\gamma\right)$ (Crittenden et al., 1998).

Four Neps (Nep1-4) are expressed in the Drosophila CNS (Meyer et al., 2011; Sitnik et al., 2014). We previously showed that they were involved in both middle-term (MTM) and long-term memory (LTM) in the dorsal paired medial (DPM) neurons, a pair of large neurons that broadly innervate all the MB lobes (Turrel et al., 2016). DPM neurons are thought to regulate the MB outcome with a feedback system, a process involved in MTM formation (Keene et al., 2004). Nep1 expression is also required in the MB for MTM and LTM, and functional redundancy is observed between Nep2, Nep3, and Nep4 for LTM formation in the MB (Turrel et al., 2016). The Nep targets involved in memory processes are still unknown.

The fly expresses a single nonessential APP ortholog called APP-Like (APPL) (Rosen et al., 1989; Luo et al., 1992). Importantly, APPL follows proteolytic pathways similar to APP (Poeck et al., 2012), and the homologs of all mammalian secretases have been characterized in the fly (Rooke et al., 1996; Boulianne et al., 1997; Hong and Koo, 1997; Carmine-Simmen et al., 2009). APPL silencing in the MB of adult flies was shown to specifically disrupt MTM and LTM (Goguel et al., 2011; Bourdet et al., 2015a).

It has been shown previously that Nep2 can degrade human A $\beta 42$ (Finelli et al., 2004; Cao et al., 2008). However, whether or not a Drosophila Nep degrades endogenous $\mathrm{A} \beta$ is still an open question. Although there is no sequence similarity at the level of A $\beta$ sequences between APP and APPL, a Drosophila A $\beta$-like peptide $(\mathrm{dA} \beta)$ was identified in old flies overexpressing APPL (Carmine-Simmen et al., 2009).

In the work reported here, using conditional expression, we modulated Nep1 and $\mathrm{dA} \beta$ levels in young adult flies. Together, our findings reveal a functional interaction between Nep1 and amyloid peptide for memory processes.

\section{Materials and Methods}

Drosophila stocks. D. melanogaster wild-type strain Canton Special (CS) and mutant flies were raised on standard medium at $18^{\circ} \mathrm{C}$ and $60 \%$ humidity with a $12 \mathrm{~h}$ light/dark cycle. All the strains used for memory experiments were outcrossed to the CS background. Nep1 and Appl$R N A i$ lines were obtained from the Vienna Drosophila Resource Center (Nep1A: 27537; Nep1C: 108860; Appl: 108312 and 42673). To overexpress Nep1, we used the P\{EPgy2\}Nep1 ${ }^{\text {EY21255 }}$ line $\left(\mathrm{Nep} 1^{\text {EY21255 }}\right.$ ) obtained from the Bloomington Drosophila Stock Center (Indiana University, \#22465). UAS-APPL (APPL) was previously described by Torroja et al. (1999). UAS-dA $\beta$ (dA $\beta$ ) and UAS-dBACE (dBACE) were kindly provided by Doris Kretzschmar (Carmine-Simmen et al., 2009). To generate a Nep1 mutant, a $2.59 \mathrm{~kb}$ PCR fragment was amplified using the Nep1 cDNA as a template (Drosophila Genomics Resource Center, Bloomington, IN, \#GH03315), and cloned into the BglII site of pUAST (Brand and Perrimon, 1993). The resulting plasmid was verified by sequencing, and the $1.24 \mathrm{~kb}$ BstEII-KpnI restriction fragment was replaced by the mutant fragment obtained from GenScript. The mutated Nep1 (Nep1 ${ }^{\text {mut }}$ ) displays a mutation in position $685(\mathrm{E} \rightarrow \mathrm{V})$ that disrupts the catalytic activity of the enzyme (Devault et al., 1988). GAL4 drivers used were VT64246 (Vienna Drosophila Resource Center, \#264246) for expression in DPM neurons and $c 739$ for expression in $\mathrm{MB} \alpha / \beta$ neurons. We used the TARGET system to specifically induce RNAi expression in adults
(McGuire et al., 2003). To achieve GAL4 induction, flies were kept at $30^{\circ} \mathrm{C}$ for $3 \mathrm{~d}$ before conditioning, and until memory test for LTM analyses.

Behavioral experiments. Flies were trained with classical olfactory aversive conditioning protocols as described by Pascual and Preat (2001). Training and testing were performed at $25^{\circ} \mathrm{C}$ and $80 \%$ humidity. Conditioning was performed on samples of 25-35 flies between 4 and $5 \mathrm{~d}$ of age with 3-octanol ( 95\% purity, Sigma-Aldrich) and 4-methylcyclohexanol (99\% purity, Sigma-Aldrich) at $0.360 \mathrm{~mm}$ and $0.325 \mathrm{~mm}$, respectively. Odors were diluted in paraffin oil (VWR International). Memory tests were performed with a T-maze apparatus (Tully and Quinn, 1985). Flies were given 1 min to choose between two arms, each delivering a distinct odor. An index was calculated as the difference between the numbers of flies in each arm divided by the number in both. The average of two reciprocal experiments gave a performance index. For learning analyses, flies were tested immediately after a single training cycle. To assess MTM, flies underwent one-cycle training, and memory was tested $2 \mathrm{~h}$ later. For LTM analyses, flies were trained with 5 cycles spaced at 15 min rest intervals, and tested $24 \mathrm{~h}$ later. For odor avoidance tests after electric shock and response to electric shock, flies were treated as described by Pascual and Preat (2001). For experiments including genotypes with a construct on the X chromosome (Nep1 ${ }^{\mathrm{EY} 21255}$ and dBACE), only females were analyzed.

$q P C R$ analyses. For elav genotypes, flies were raised at $25^{\circ} \mathrm{C}$. Galso ${ }^{t s}$; VT64246 flies were raised at $18^{\circ} \mathrm{C}$, and GAL4-transcription was induced for $3 \mathrm{~d}$ at $30^{\circ} \mathrm{C}$ before RNA extraction. Total RNA was extracted from 60 female heads using the RNeasy Plant Mini Kit (QIAGEN). Preparations underwent a DNaseI treatment (Biolabs) for $15 \mathrm{~min}$ at $37^{\circ} \mathrm{C}$. DNase was heat-inactivated with EDTA $(10 \mathrm{~mm})$. Samples were cleaned with the RNA Minielute Cleanup kit (QIAGEN), and reverse-transcribed with oligo(dT)20 primers using the SuperScript III First-Strand kit (Invitrogen) according to the manufacturer's instructions. Level of the target cDNA was compared against level of $\alpha$-Tub84B (Tub, CG1913) cDNA used as a reference. Amplification was performed using a LightCycler 480 (Roche) and the SYBR Green I Master mix (Roche). Reactions were performed in triplicate. Specificity and size of amplification products were assessed by melting curve analyses and agarose gel electrophoresis, respectively. Expression relative to reference is expressed as a ratio $\left(2^{-\Delta C p}\right.$, where $C p$ is the crossing point).

Western blot analyses. To analyze $\mathrm{dA} \beta$ level, we used a $t u b-G a l 80^{\text {ts }}$;elav pan-neuronal driver. Proteins were extracted from 50 female fly heads after $48 \mathrm{~h}$ of induction at $30^{\circ} \mathrm{C}$. Samples were prepared as in Burnouf et al. (2015). Soluble proteins were separated using SDS-PAGE gels containing a gradient of $10 \%-20 \%$ acrylamide (Novex 10\%-20\% Tricine, Invitrogen) and transferred to nitrocellulose membrane (GE Healthcare). Membranes were cut into two parts: the lower one was probed with anti-HA (ab130275, Abcam, 1:10,000 dilution), and the upper one was probed with anti- $\alpha$-Tub (T6199; Sigma-Aldrich, 1:40,000 dilution). Western blots were routinely developed using the ECL system (Invitrogen). Protein levels were quantified using ImageQuant TL software (GE Healthcare) and expressed as a ratio relative to $\alpha$-Tub.

Experimental design and statistical analyses. For behavioral experiments, memory scores were displayed as mean \pm SEM. Scores resulting from all genotypes were analyzed using one-way ANOVA followed, if significant at $p \leq 0.05$, by Newman-Keuls multiple-comparison tests. Overall, ANOVA $p$ value is given in the legends along with the value of the corresponding Fisher distribution $F_{(x, y)}$, where $x$ is number of degrees of freedom for groups and $y$ is the total number of degrees of freedom for the distribution. Asterisks in the figure denote the least significant of the pairwise post hoc comparisons between the genotype of interest and its controls, following the usual nomenclature. Quantitative mRNA measurements were analyzed from $2^{-\Delta \mathrm{CP}}$ using Student's $t$ tests, with significance threshold set at $p \leq 0.05$. Western blot quantification was analyzed using Student's one-sample $t$ test.

\section{Results}

\section{Modulation of Nep1 expression in the adult MB does not impact memory of flies expressing $\mathrm{dA} \beta$}

We previously showed that Nep1 expression is required in the $\alpha / \beta$ neurons of the MB for MTM (Turrel et al., 2016). Using a 
A

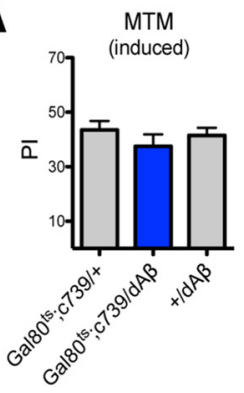

C

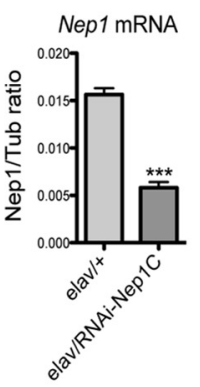

B

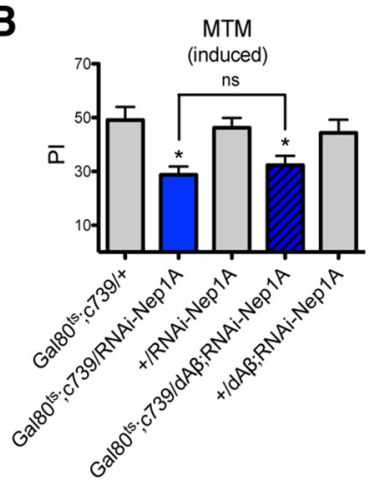

D

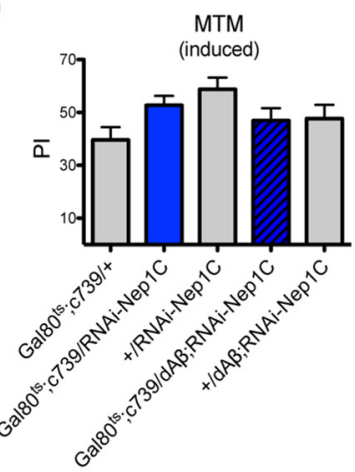

E
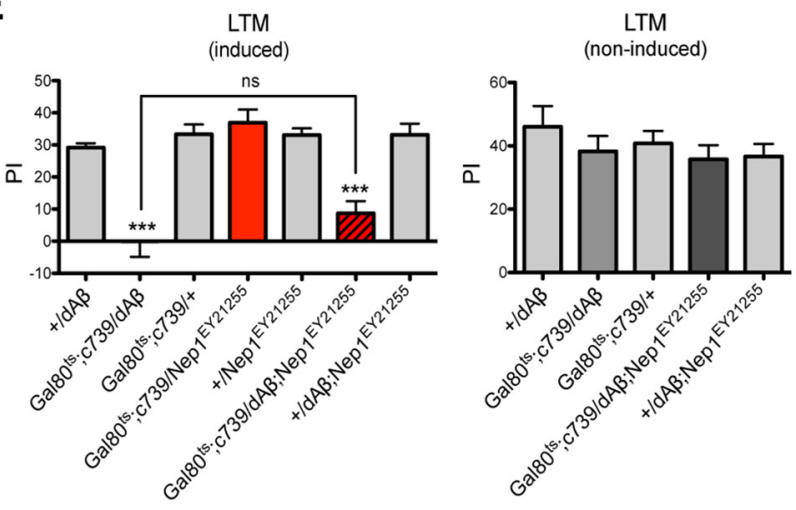

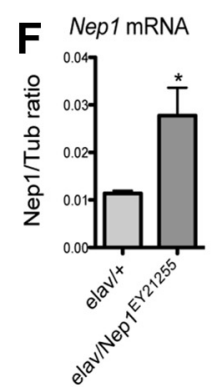

Figure 1. Modulation of Nep1 expression in the adult MB does not impact memory of flies expressing $\mathrm{dA} \beta . A, \mathrm{dA} \beta$ expression in $\alpha / \beta$ neurons does not alter $\operatorname{MTM}\left(F_{(2,35)}=0.7471, p=\right.$ $0.4816, n=12) . B, \mathrm{dA} \beta$ expression in $\alpha / \beta$ neurons does not aggravate the MTM defect caused by RNAi-Nep1A expression. Gal80 $0^{\text {ts }} ; 7339 / d A \beta ; R N A i-N e p 1 A$ flies exhibit an MTM deficit that is not significantly different from that of Gal80 $;$; $7739 /$ RNAi-Nep1A flies $\left(F_{(4,69)}=5.086, p=\right.$ $0.0013, n \geq 14$, post hoc Newman-Keuls test, ${ }^{* *} p<0.01$, Gal80 ${ }^{\text {ts }}$ c739/RNAi-Nep1A versus Gal80 $;$; $c 739 /+.{ }^{*} p<0.05$, Gal80 ${ }^{\text {ts }} ;$ c739/RNAi-Nep1A versus +/RNAi-Nep1A. $p>0.05$,

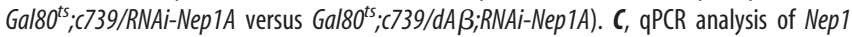
mRNA targeting by the RNAi-Nep1C construct. Total RNA was extracted from elav/+ and elav/ RNAi-Nep1C fly heads, and further reverse-transcribed with oligo(dT) primers. Resulting CDNA was quantified using Tub expression as a reference. Results are shown as ratios to the reference (unpaired $t$ test, $t_{(6)}=11.07,{ }^{* * *} p<0.0001, n=4$ ) (4 values from two independent RNA

Table 1. Shock reactivity and olfactory acuity of flies expressing $\mathrm{dA} \beta$ in adult $\alpha / \beta$ neurons ${ }^{a}$

\begin{tabular}{llll}
\hline & & \multicolumn{2}{l}{ Olfactory acuity } \\
\cline { 3 - 4 } Genotype & Shock reactivity & Octanol & Methylcyclohexanol \\
\hline Gal $80^{t 5} ; c 739 /+$ & $71.89 \pm 4.101$ & $44.18 \pm 6.630$ & $55.58 \pm 8.198$ \\
Gal $80^{t 5} ;$; $739 / d A \beta$ & $68.56 \pm 2.799$ & $36.45 \pm 6.742$ & $49.25 \pm 7.248$ \\
$+/ d A \beta$ & $63.11 \pm 3.405$ & $37.00 \pm 6.520$ & $45.27 \pm 10.54$ \\
\hline
\end{tabular}

${ }^{a}$ Data are mean \pm SEM. After $3 \mathrm{~d}$ of induction, neither shock reactivity $\left(F_{(2,2)}=1.625, p=0.2179, n=9\right)$ nor olfactory acuity for octanol $\left(F_{(2,32)}=0.4229, p=0.6590, n=11\right)$ and methylcyclohexanol $\left(F_{(2,34)}=0.3573\right.$, $p=0.7,24, n \geq 11)$ is impaired in flies expressing $\mathrm{dA} \beta$ under the control of the $G$ al $80^{t s} ;(739$ driver.

classical conditioning paradigm in which an odorant is paired with the delivery of electric shocks, the fly is able to form six discrete aversive memory phases reflected at the neural network level (Bouzaiane et al., 2015). Learning is measured immediately after a single conditioning, whereas MTM is assessed $1-3 \mathrm{~h}$ later. The fly can also produce two antagonistic forms of consolidated memory (Isabel et al., 2004). Among them, the robust LTM is only formed after multiple conditioning cycles spaced by rest intervals. Crucially, LTM is the only memory phase-dependent on de novo protein synthesis (Tully et al., 1994).

To find out whether amyloid peptide was a target for Nep1 for memory processes, we proceeded to modulate Nepl expression in transgenic flies expressing Drosophila amyloid peptides. To this end, we used a construct allowing expression of a $\mathrm{dA} \beta$ derived from APPL (Carmine-Simmen et al., 2009). dA $\beta$ ectopic expression in the MB was achieved with the $\mathrm{c} 739$ driver that labels the $\alpha / \beta \mathrm{KC}$ (Yang et al., 1995). To restrict GAL4 expression to adulthood, we used a tubGal80 $0^{t s} ; \mathrm{c} 739$ line (Gal80 $\left.{ }^{t s} ; \mathrm{c} 739\right)$ that ubiquitously expresses a thermosensitive GAL4 inhibitor $\left(\mathrm{Gal} 80^{\text {ts }}\right)$ inactive at $30^{\circ} \mathrm{C}$ (McGuire et al., 2003). As previously shown (Bourdet et al., 2015b), dA $\beta$ expression in the adult $\alpha / \beta \mathrm{KC}$ did not impair MTM (Fig. $1 A$ ). To determine whether Nep1 could functionally interact with $\mathrm{dA} \beta$, we examined whether the MTM deficit displayed by Nep1-knockdown flies (Turrel et al., 2016) was exacerbated by dA $\beta$ expression: if Nep1 degrades $\mathrm{dA} \beta$, then Nep1 knockdown should lead to an increase in $\mathrm{dA} \beta$ level that might impair MTM formation.

To reduce Nep1 expression, we used specific RNAi constructs. The RNAi-Nep1A construct leads to a $75 \%$ decrease in Nep1 expression in elav/RNAi-Nep1A flies and caused an MTM deficit when expressed in adult $\alpha / \beta \mathrm{KC}$ (Turrel et al., 2016). Concomitant $\mathrm{dA} \beta$ overexpression did not further affect MTM of RNAi-Nep1A-expressing flies (Fig. 1B). We next used a second nonoverlapping construct, RNAi-Nep1C. qPCR experiments showed that elav/RNAi-Nep1C flies exhibited a $63 \%$ decrease in

$\leftarrow$

extractions). $\boldsymbol{D}, \mathrm{dA} \beta$ expression in $\alpha / \beta$ neurons does not alter MTM of RNAi-Nep1C-expressing

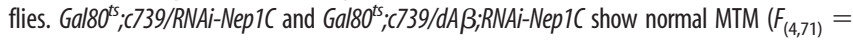
$2.354, p=0.0626, n \geq 14)$. $E$, Flies expressing $\mathrm{dA} \beta$ in $\alpha / \beta$ neurons present an LTM deficit that is not alleviated by Nep1 overexpression. Gal80 ${ }^{5} ; 7739 / d A \beta$ flies exhibit an LTM deficit $\left(F_{(6,83)}=\right.$ $17.86, p<0.0001, n=12$, post hoc Newman-Keuls test, ${ }^{* * *} p<0.001$, Gal80 $;$; $c 739 / \mathrm{dA} \beta$ versus Gal80 $0^{\text {t5 }} ; 7739 /+{ }^{* * *} p<0.001$, Gal80 ${ }^{\text {t5 }} ; 7739 / d A \beta$ versus $\left.+/ d A \beta\right)$. Flies overexpressing

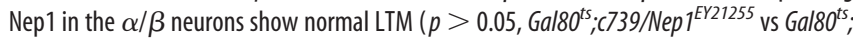

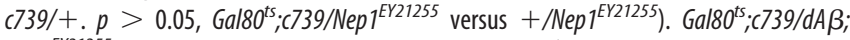

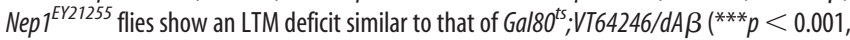

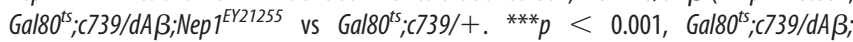

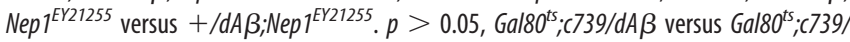
$d A \beta ; N$ Nep $\left.1^{E Y 21255}\right)$. In the absence of induction, all genotypes exhibit normal $L T M$ scores $\left(F_{(4.59)}=\right.$ $0.7078, p=0.5901, n=12) . F, q P C R$ analysis of Nep1 overexpression using the Nep $1^{\text {EY2125 }}$

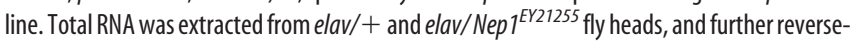
transcribed with oligo(dT) primers. Resulting CDNA was quantified using Tub expression as a reference. Results are shown as ratios to the reference (unpaired $t$ test, $t_{(14)}=2.761,{ }^{*} p=$ $0.0153, n=8)$ ( 8 values from four independent RNA extractions). 
A

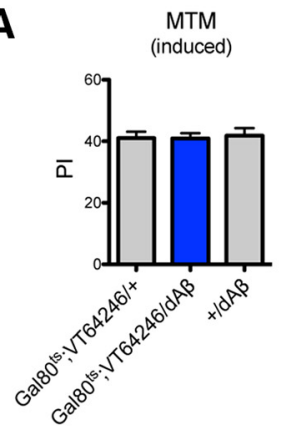

B

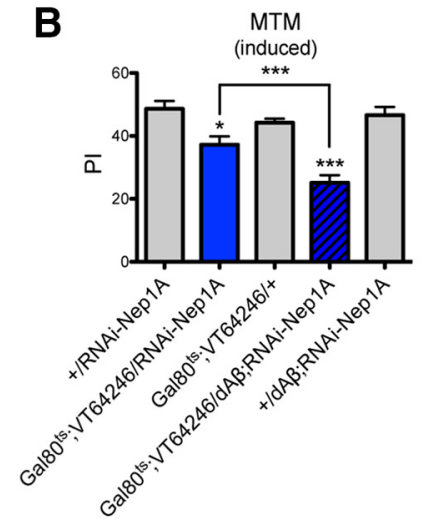

D

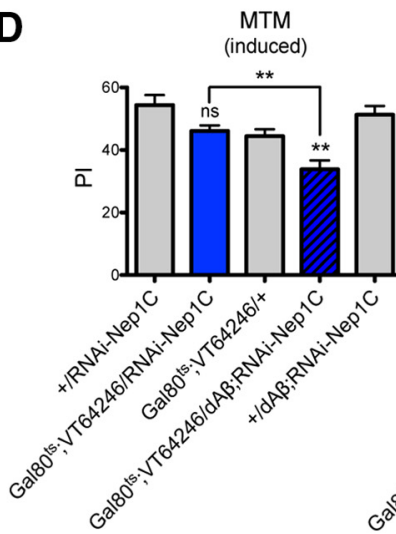

MTM (non-induced)

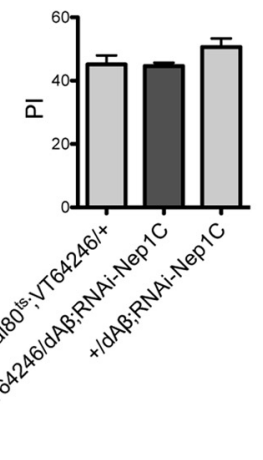

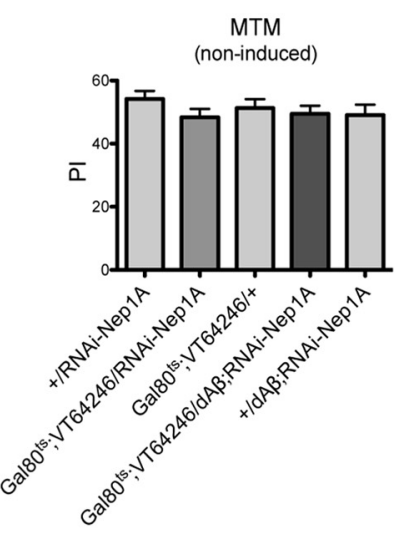

E
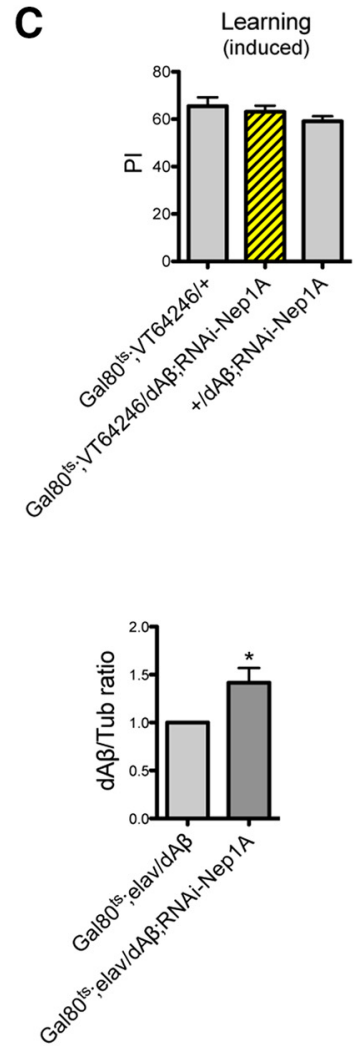

Figure 2. $\mathrm{dA} \beta$ expression is detrimental to MTM formation when combined with Nep 1 knockdown in adult DPM neurons. $A$, Flies expressing dA $\beta$ in adult DPM neurons show normal MTM $\left(F_{(2,32)}=\right.$ $0.0550, p=0.9466, n=11) \cdot \boldsymbol{B}$, dA $\beta$ expression in Nep1-knockdown flies exacerbates their MTM deficit. Gal80 $;$ VVT64246/RNAi-Nep1A flies exhibit an MTM deficit $\left(F_{(4,69)}=17.62, p<0.0001, n \geq\right.$ 13, post hoc Newman-Keuls test, ${ }^{*} p<0.05$, Gal80 ; VT64246/RNAi-Nep1A versus Gal80 ; VT64246/+. ${ }^{* *} p<0.01$, Gal80 $;$; VT64246/RNAi-Nep1A versus +/RNAi-Nep1A), which is aggravated by

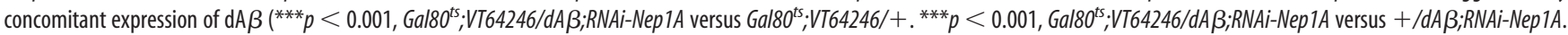
${ }^{* * *} p<0.001$, Gal80 ${ }^{\text {ts }}$ VVT64246/dA $\beta ;$ RNAi-Nep1A versus Gal80's; VT64246/RNAi-Nep 1A). In the absence of induction, all genotypes exhibit normal MTM scores $\left(F_{(4,54)}=0.6991, p=0.5962, n=\right.$ 11). C, Learning is not affected by dA $\beta$ expression and concomitant Nep1 knockdown in DPM neurons $\left(F_{(2,23)}=1.251, p=0.3066, n=8\right)$. $\boldsymbol{D}$, Flies expressing RNAi-Nep1C do not exhibit an MTM deficit $\left(F_{(4,80)}=8.951, p<0.0001, n \geq 16\right)$. In contrast, RNAi-Nep1C coexpression with dA $\beta$ in adult DPM neurons induces an MTM deficit ${ }^{* * *} p<0.01$, Gal80 ; VT64246/dA $\beta$; RNAi-Nep1C versus

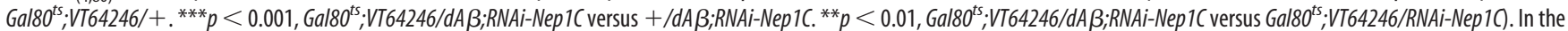
absence of induction, all genotypes exhibit normal $\operatorname{MTM}$ scores $\left(F_{(3,66)}=3.655, p=0.0170, n=17\right) . E$, dA $\beta$ level is increased when Nep1 is knocked down. Western blot analyses. Left, Membranes were cut in two halves: the upper part was stained using an $\alpha$-Tub antibody, and the lower part was stained using an HA-specific antibody. Right, Quantification. $\mathrm{dA} \beta$ is expressed as a ratio to $\alpha$-Tub, relative to the Gal80 ${ }^{t \text {; }}$ elav/dA $\beta$ control (one-sample $t$ test $, t_{(7)}=2.712,{ }^{*} p=0.0301, n=8$ ) (8 values from eight independent extractions). Error bar indicates SEM.

Nep1 expression (Fig. 1C). We further observed that reducing Nep1 expression in adult $\alpha / \beta \mathrm{KC}$ to a smaller extent than that previously achieved with the RNAi-Nep1A construct appeared to have no impact on MTM (Fig. 1D). Concomitant dA $\beta$ overexpression did not alter MTM (Fig. 1D). Thus, reducing Nep1 level in adult $\alpha / \beta \mathrm{KC}$ of flies expressing amyloid peptide did not reveal any functional interaction between Nep1 and dA $\beta$.

We next analyzed LTM and observed that Gal80 ${ }^{\text {ts }} ; \mathrm{c} 739 / \mathrm{dA} \beta$ induced flies displayed a severe LTM defect, whereas noninduced flies showed normal LTM scores (Fig. 1E). We analyzed the sensory-motor capacities of the Gal80 ${ }^{t s} ; c 739 / d A \beta$ flies, and found that they displayed normal shock reactivity and olfactory acuity (Table 1). We conclude that $\mathrm{dA} \beta$ expression in adult $\alpha / \beta \mathrm{KC}$ induces an LTM deficit. We thus asked whether Nep1 overexpression would alleviate the LTM defect caused by dA $\beta$ expression. To this end, we took advantage of the Nep1 $1^{E Y 21255}$ line that contains a P-element inserted upstream of the first noncoding Nep1-RA exon. This P-element construct carries UAS binding sites for the GAL4 transcriptional regulator, allowing GAL4mediated expression of genes proximate to the site of the insertion (Bellen et al., 2004). It was previously shown that this line allows Nep1 overexpression (Panz et al., 2012). We performed
Table 2. Shock reactivity and olfactory acuity of flies expressing $\mathrm{dA} \beta$ and Nep1-RNAi in adult DPM neurons ${ }^{a}$

\begin{tabular}{|c|c|c|c|}
\hline \multirow[b]{2}{*}{ Genotype } & \multirow[b]{2}{*}{ Shock reactivity } & \multicolumn{2}{|l|}{ Olfactory acuity } \\
\hline & & Octanol & Methylcyclohexanol \\
\hline 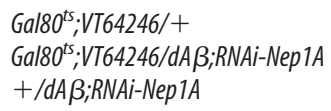 & $\begin{array}{l}66.20 \pm 3.133 \\
65.00 \pm 3.697 \\
70.40 \pm 3.246\end{array}$ & $\begin{array}{l}38.40 \pm 1.485 \\
39.90 \pm 2.900 \\
36.20 \pm 1.825\end{array}$ & $\begin{array}{l}52.80 \pm 7.513 \\
57.50 \pm 2.655 \\
56.00 \pm 5.914\end{array}$ \\
\hline 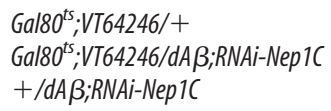 & $\begin{array}{l}63.50 \pm 4.856 \\
64.00 \pm 5.510 \\
55.80 \pm 4.299\end{array}$ & $\begin{array}{l}50.60 \pm 3.387 \\
54.10 \pm 2.938 \\
55.30 \pm 4.828\end{array}$ & $\begin{array}{l}51.00 \pm 2.039 \\
59.30 \pm 5.281 \\
49.10 \pm 2.433\end{array}$ \\
\hline
\end{tabular}

${ }^{a}$ Data are mean \pm SEM. After 3 d of induction, neither shock reactivity (dA $\beta ; R N A i-N e p 1 A: F_{(2,29)}=0.7089, p=$ $0.5011, n=10$; dA $\beta$;RNAi-Nep1C: $F_{(2.29)}=0.8753, p=0.4282, n=10$ ) nor olfactory acuity for octanol ( $\mathrm{dA} \beta$; RNAi-Nep1A: $F_{(2,29)}=0.7452, p=0.4842, n=10 ; \mathrm{dA} \beta ;$ RNAi-Nep1C: $\left.F_{(2,29)}=0.4121, p=0.6664, n=10\right)$ and methylcyclohexanol (dA $\beta ;$ RNAi-Nep1A: $F_{(2,29)}=0.1756, p=0.8399, n=10 ; \mathrm{dA} \beta ;$ RNAi-Nep1C: $F_{(2,29)}=2.325$, $p=0.1171, n=10)$ is impaired in flies expressing $\mathrm{dA} \beta$ and Nep1-RNAi under the control of the Gal $80^{15}$;VT64246 driver.

qPCR experiments to assess Nep1 expression level in elav/ Nep $1^{E Y 21255}$ flies. The data show that fly heads express a 2.4-fold increase in Nep1 mRNA level (Fig. $1 F$ ).

Flies overexpressing Nep1 $\left(\right.$ Gal80 $;$; $\left.7339 / N e p 1^{E Y 21255}\right)$ showed normal LTM (Fig. 1E). Simultaneous overexpression of Nep1 and $\mathrm{dA} \beta$ in adult $\alpha / \beta \mathrm{KC}$ did not rescue the LTM deficit caused 
A

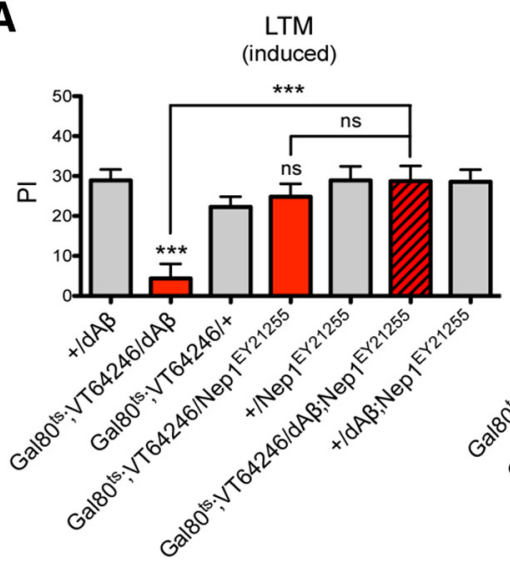

LTM (non-induced)

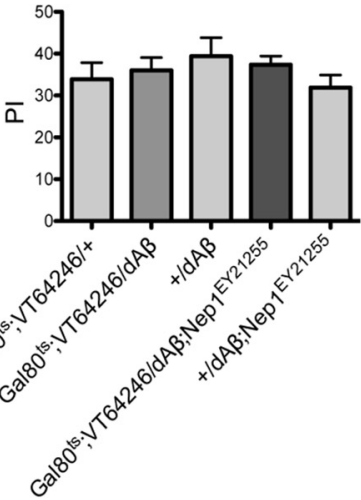

D (induced)

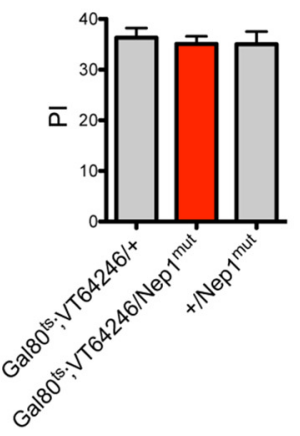

E

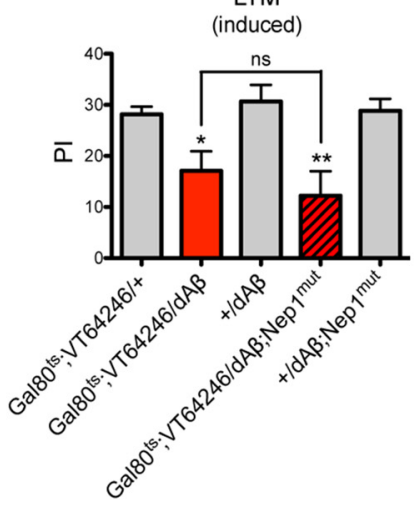

B

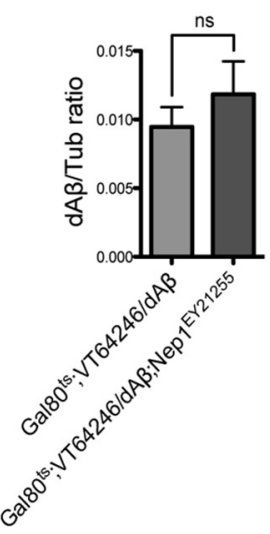

LTM

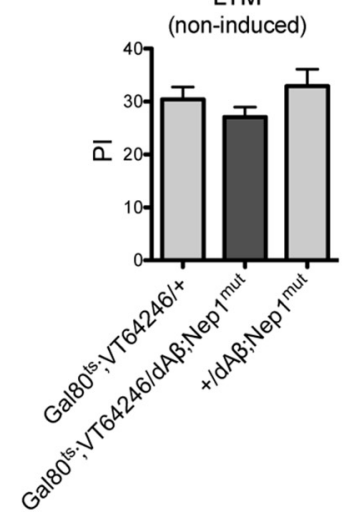

C

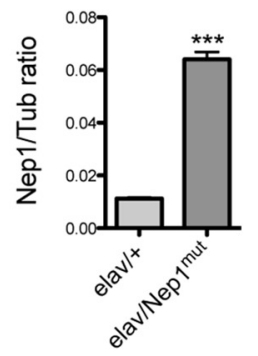

Figure 3. Nep1 overexpression in adult DPM neurons rescues the LTM defect caused by $\mathrm{dA} \beta$ expression. $A$, Nep1 overexpression in adult DPM neurons rescues the LTM deficit of $\mathrm{dA} \beta$-expressing flies. Flies expressing $\mathrm{dA} \beta$ in DPM neurons exhibit a strong LTM defect $\left(F_{(6,74)}=7.606, p<0.0001, n \geq 10\right.$, post hoc Newman-Keuls test, ${ }^{* * *} p<0.001$, Gal80 ${ }^{t 5}$;VT64246/dA $\beta$ versus

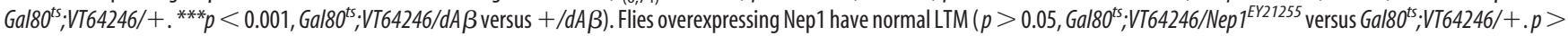

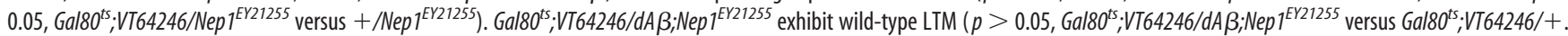

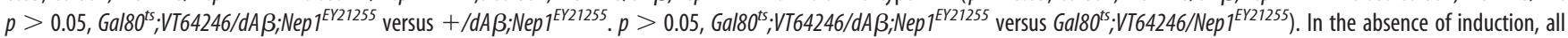
genotypes exhibit normal LTM scores $\left(F_{(6,73)}=0.6718, p=0.6727, n \geq 10\right) . B, \mathrm{dA} \beta$ expression is not decreased by Nep ${ }^{\mathrm{EY} 21255}$ presence. qPCR analyses of $\mathrm{dA} \beta$ mRNA levels. Total RNA was

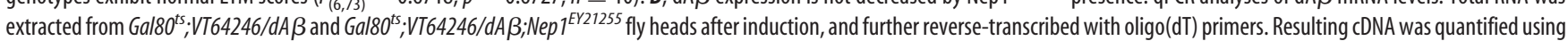
Tub expression as a reference. Results are shown as ratios to the reference (unpaired $t$ test, $t_{(5)}=2.774, p=0.4162, n=6$ ) ( 6 values from three independent RNA extractions). $C$, $q \mathrm{PCR}$ analysis of Nep $1^{\text {mut }}$ expression. Total RNA was extracted from elav/+ and elav/Nep $1^{\text {mut }}$ fly heads, and further reverse-transcribed with oligo(dT) primers. Resulting cDNA was quantified using Tub expression as a reference. Results are shown as ratios to the reference (unpaired $t$ test, $\left.t_{(10)}=18.55,{ }^{* * *} p<0.0001, n=6\right)\left(6\right.$ values from three independent RNA extractions). D, Flies overexpressing Nep ${ }^{\text {mut }}{ }_{\text {, }}^{\text {, }}$ a mutant inactive Nep1 form, in adult DPM neurons, show normal $\operatorname{LTM}\left(F_{(2,35)}=0.1371, p=0.8724, n=12\right)$. , Nep1 $^{\text {mut }}$ expression does not rescue the LTM deficit caused by dA $\beta\left(F_{(4,109)}=\right.$ $6.035, p=0.0002, n=22$, post hoc Newman-Keuls test, ${ }^{*} p<0.05$, Gal80 ${ }^{t 5} ; V T 64246 / d A \beta$ vs Gal80 ; $;$ VT64246/+. ${ }^{*} p<0.05$, Gal80 $;$; VT64246/dA $\beta$ vs $+/ d A \beta$. ${ }^{* *} p<0.01$, Gal80 $;$;VT64246/

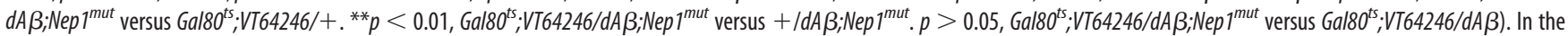
absence of induction, all genotypes exhibit normal $\operatorname{LTM} \operatorname{scores}\left(F_{(4,59)}=1.575, p=0.1939, n=12\right)$.

by $\mathrm{dA} \beta$ expression (Fig. $1 E$ ). In conclusion, we did not observe any functional interaction when Nep1 expression was modulated in the $\mathrm{MB}$ of $\mathrm{dA} \beta$-expressing flies.

\section{$\mathrm{dA} \boldsymbol{\beta}$ expression impairs MTM formation when combined with Nep1 knockdown in adult DPM neurons}

As Nep1 expression was also shown to be required in DPM neurons for memory formation (Turrel et al., 2016), we repeated the experiments using a $t u b-G a l 80^{t s}$;VT64246 GAL4-line (Gal80 ${ }^{t s}$; $V T 64246$ ) to drive specific expression in adult DPM neurons. We first expressed $\mathrm{dA} \beta$ in adult DPM neurons. Like $\mathrm{dA} \beta$ expression driven in $\mathrm{KC}$, expression driven in adult DPM neurons did not impact MTM (Fig. 2A). As previously reported (Turrel et al., 2016), RNAi-Nep1A expression in adult DPM neurons led to an MTM defect (Fig. 2B). Strikingly, concomitant dA $\beta$ expression aggravated the MTM defect caused by Nep1 inhibition in DPM neurons (Fig. 2B). In the absence of GAL4 induction, all geno-
Table 3. Shock reactivity and olfactory acuity of flies expressing $\mathrm{dA} \beta$ in adult DPM neurons ${ }^{a}$

\begin{tabular}{|c|c|c|c|}
\hline \multirow[b]{2}{*}{ Genotype } & \multirow[b]{2}{*}{ Shock reactivity } & \multicolumn{2}{|l|}{ Olfactory acuity } \\
\hline & & Octanol & Methylcyclohexanol \\
\hline Gal80 $;$ it VT64246/+ & $71.70 \pm 3.422$ & $50.80 \pm 5.092$ & $56.20 \pm 6.771$ \\
\hline Gal80 ${ }^{t s} ; V T 64246 / d A \beta$ & $63.90 \pm 3.121$ & $47.70 \pm 6.035$ & $49.90 \pm 5.023$ \\
\hline$+/ d A \beta$ & $59.00 \pm 4.683$ & $48.70 \pm 7.030$ & $56.30 \pm 4.522$ \\
\hline
\end{tabular}

${ }^{a}$ Data are mean \pm SEM. After $3 \mathrm{~d}$ of induction, neither shock reactivity $\left(F_{(2,29)}=2.836, p=0.0762, n=10\right)$ nor olfactory acuity for octanol $\left(F_{(2,29)}=0.0672, p=0.9352, n=10\right)$ and methylcyclohexanol $\left(F_{(2,29)}=0.4407, p=\right.$ $0.6481, n=10)$ is impaired in flies expressing $\mathrm{dA} \beta$ under the control of the $G a / 80^{t 5} ; \mathrm{VT} 64246$ driver.

types showed normal MTM scores (Fig. $2 B$ ). We verified that the ability of induced $G a l 80^{\text {ts }}$;VT64246/dA $3 ; R N A i-N e p 1 A$ flies to avoid electric shocks and their olfactory acuity to each odor after electric shock exposure, were unaffected (Table 2). We next analyzed learning capacity and observed that, like $\mathrm{Gal}^{\mathrm{ts}}$; $V T 64246 /$ RNAi-Nep1A flies (Turrel et al., 2016), Gal80 ${ }^{t s} ; V_{T 64246 / d A \beta}$; 
A

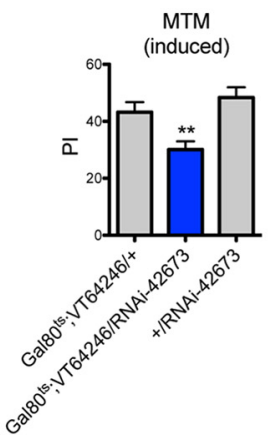

B

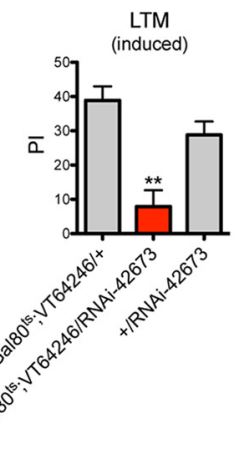

C

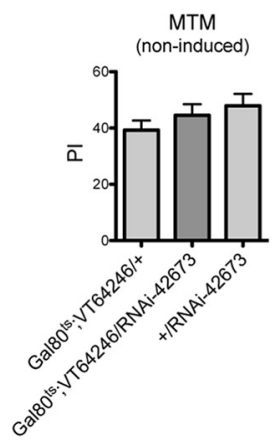

D

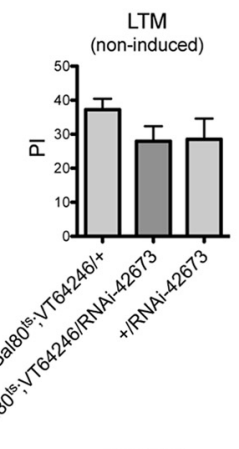

E

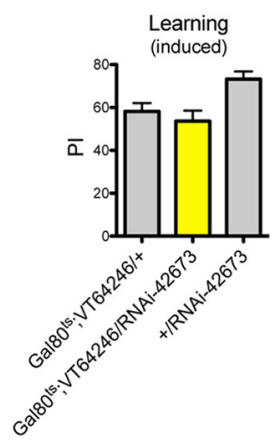

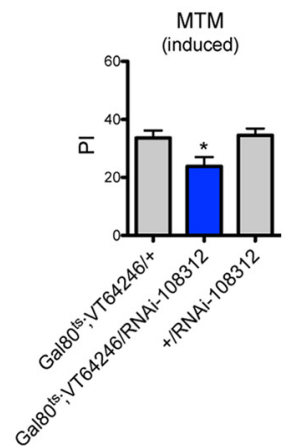
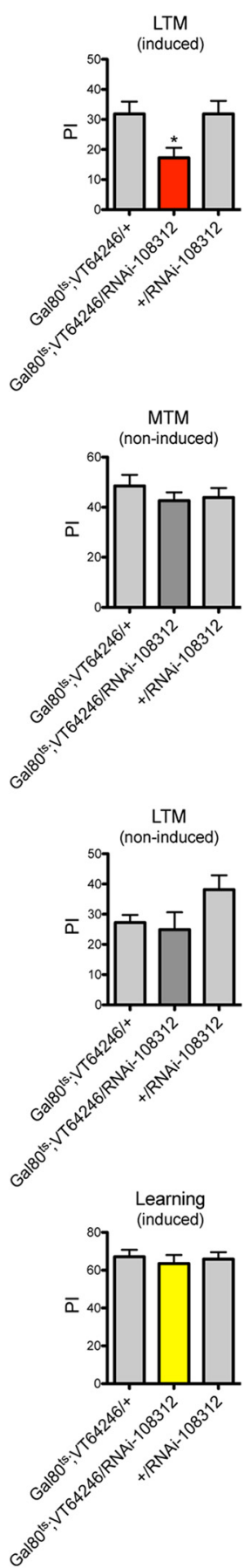

Figure 4. APPL expression is required in adult DPM neurons for MTM and LTM. $A$, Flies expressing APPL-RNAi in adult DPM neurons present MTM defects (RNAi-42673: $F_{(2,41)}=$ $7.990, p=0.0012, n=14$, post hoc Newman-Keuls test, ${ }^{* *} p<0.01$, Gal80 ; VT64246/

Table 4. Shock reactivity and olfactory acuity of flies expressing APPL-RNAi in adult DPM neurons $^{a}$

\begin{tabular}{|c|c|c|c|}
\hline \multirow[b]{2}{*}{ Genotype } & \multirow[b]{2}{*}{ Shock reactivity } & \multicolumn{2}{|l|}{ Olfactory acuity } \\
\hline & & Octanol & Methylcyclohexanol \\
\hline Gal80 $; V T 64246 /+$ & $73.92 \pm 5.447$ & $55.80 \pm 5.557$ & $47.80 \pm 5.142$ \\
\hline Gal80 ${ }^{\text {ts }} ;$ VT64246/RNAi-108312 & $84.42 \pm 3.526$ & $65.30 \pm 3.652$ & $56.10 \pm 6.689$ \\
\hline$+/ 108312$ & $75.92 \pm 3.073$ & $56.30 \pm 5.365$ & $55.50 \pm 4.191$ \\
\hline Gal80'tis $V$ TT64246/+ & $76.92 \pm 4.853$ & $41.25 \pm 4.496$ & $51.75 \pm 4.563$ \\
\hline Gal80 ${ }^{\text {ts }} ; \mathrm{VT} 64246 / R N A i-42673$ & $66.92 \pm 4.920$ & $41.69 \pm 6.970$ & $48.08 \pm 6.414$ \\
\hline$+/ 42673$ & $74.33 \pm 3.085$ & $46.63 \pm 5.507$ & $50.17 \pm 6.297$ \\
\hline
\end{tabular}

${ }^{a}$ Data are mean \pm SEM. After $3 \mathrm{~d}$ of induction, neither shock reactivity (RNAi-108312: $F_{(2,35)}=1.809, p=0.1797$ $n=12 ;$ RNAi-42673: $F_{(2,35)}=1.411, p=0.2581, n=12$ ) nor olfactory acuity for octanol ( RNAi-108312: $F_{(229)}=$ $1.175, p=0.3242, n=10 ;$ RNAi-42673: $\left.F_{(2,47)}=0.2697, p=0.7649, n=16\right)$ and methylcyclohexanol (RNAi108312: $F_{(2,29)}=0.7242, p=0.4939, n=10 ;$ RNAi-42673: $\left.F_{(2,35)}=0.0999, p=0.9052, n=12\right)$ is impaired in flies expressing APPL-RNAi under the control of the Gal80 $30^{5} ;$ VT 64246 driver.

RNAi-Nep1A flies exhibited normal learning (Fig. 2C). Thus, the association of Nep1 knockdown with $\mathrm{dA} \beta$ expression in adult DPM neurons does not perturb learning.

To confirm these results, we used RNAi-Nep1C. Similarly to its expression in $\mathrm{KC}$, its expression driven in adult DPM neurons did not impact MTM (Fig. 2D), probably because this RNAi induces a smaller decrease in Nep1 than RNAi-Nep1A. Interestingly, whereas flies expressing only RNAi-Nep1C showed normal MTM, flies expressing both $\mathrm{dA} \beta$ and RNAi-Nep1C showed an MTM deficit (Fig. 2D). As expected, this deficit was not observed in the absence of GAL4 induction (Fig. 2D). We verified that the

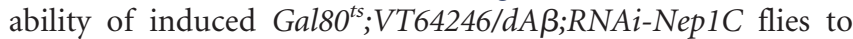
perceive conditioning stimuli was normal (Table 2). We conclude that, in DPM neurons, Nep1 reduction makes $\mathrm{dA} \beta$ overexpression detrimental for MTM, revealing a functional link between Nep1 and $\mathrm{dA} \beta$. We hypothesize that Nep1 reduction leads to a failure in $\mathrm{dA} \beta$ degradation, thus generating increased levels of $\mathrm{dA} \beta$ that impair memory.

To directly assess the effect of Nep1 inhibition on $\mathrm{dA} \beta$ levels, we used the HA tag-sequence inserted downstream of the $\mathrm{dA} \beta$ sequence (Carmine-Simmen et al., 2009). We used a tub-Gal80 $0^{\text {ts }}$; elav line $\left(\mathrm{Gals0}^{t s}\right.$;elav) to drive $\mathrm{dA} \beta$ pan-neuronal expression in adult flies. Head protein extracts were analyzed by Western blotting. Quantification revealed that $\mathrm{dA} \beta$ levels were increased when Nep1 was knocked down (Fig. 2E). The data indicate that Nep1 degrades $\mathrm{dA} \beta$, consistent with functional analyses described above.

RNAi-42673 versus Gal80's. VT64246/+. ${ }^{* *} p<0.01$, Gal80 ${ }^{\text {ts }}$.VT64246/RNAi-42673 versus $+/$ RNAi-42673; RNAi-108312: $F_{(2,37)}=4.657, p=0.0161, n \geq 12$, post hoc Newman-Keuls test, ${ }^{*} p<0.05$, Gal80 ; VT64246/RNAi-108312 versus Gal80 $0^{\text {t5 }}$,VT64246/+. ${ }^{*} p<0.05$, Gal80's VVT64246/RNAi-108312 versus + /RNAi-108312). B, Flies expressing APPL-RNAi in adult DPM neurons present LTM defects (RNAi-42673: $F_{(2,46)}=13.85, p<0.0001, n \geq 15$, post hoc

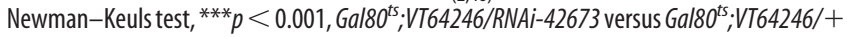
${ }^{* *} p<0.01$, Gal80 ${ }^{\text {ts }}$,VT64246/RNAi-42673 versus +/RNAi-42673; RNAi-108312: $F_{(2,63)}=$ $4.530, p=0.0146, n \geq 21$, post hoc Newman-Keuls test, ${ }^{*} p<0.05$, Gal80 ${ }^{\text {ts }}$;VT64246/RNAi108312 versus Gal80ts;VT64246/+. ${ }^{*} p<0.05$, Gal80 $0^{\text {ts }}$;VT64246/RNAi-108312 versus $+/$ RNAi-108312). C, In the absence of induction, all genotypes exhibit normal MTM scores (RNAi-42673: $F_{(2,29)}=1.250, p=0.3025, n=10 ;$ RNAi-108312: $F_{(2,23)}=0.6399, p=$ $0.5373, n=8$ ). $\boldsymbol{D}$, In the absence of induction, all genotypes exhibit normal LTM scores (RNAi42673: $F_{(2,57)}=1.213, p=0.3051, n \geq 19 ;$ RNAi-108312: $F_{(2,59)}=2.506, p=0.0905, n \geq$ 19). $\boldsymbol{E}$, Learning is not affected by APPL-RNAi expression in adult DPM neurons (RNAi-42673: $F_{(2,23)}=6.108, p=0.0081, n=8$, post hoc Newman-Keuls test, $p>0.05$, Gal $80^{\text {ts }} ;$ VT64246/ RNAi-42673 versus Gal80 ${ }^{\text {ts }}$ VVT64246/+. ${ }^{* *} p<0.01$, Gal80 ${ }^{\text {ts }}$; VT64246/RNAi-42673 versus $+/$ RNAi-42673; RNAi-108312: $\left.F_{(2,23)}=0.6399, p=0.5373, n=8\right)$. 
A

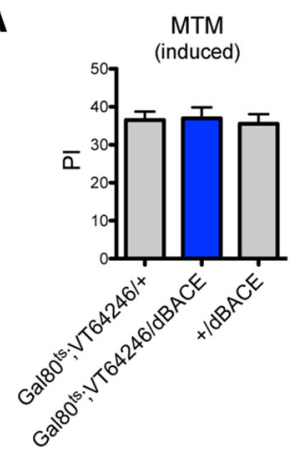

B

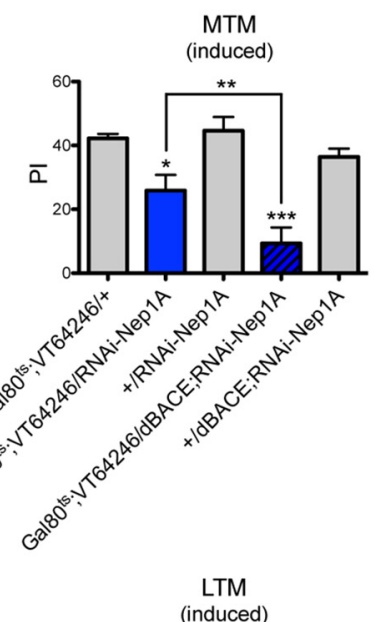

C

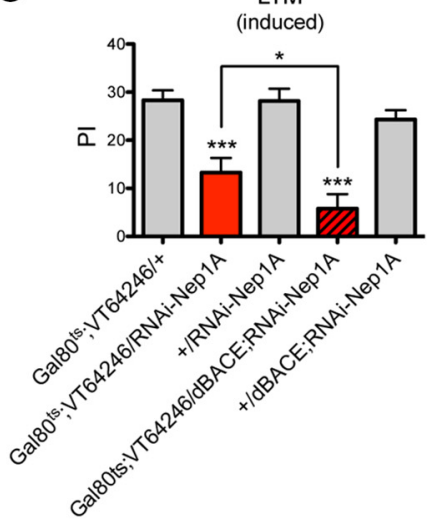

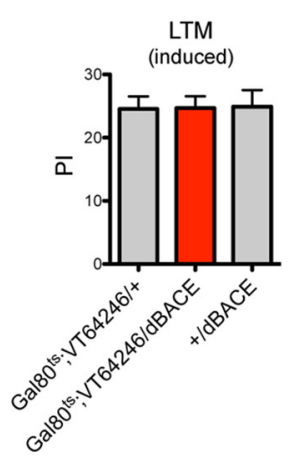
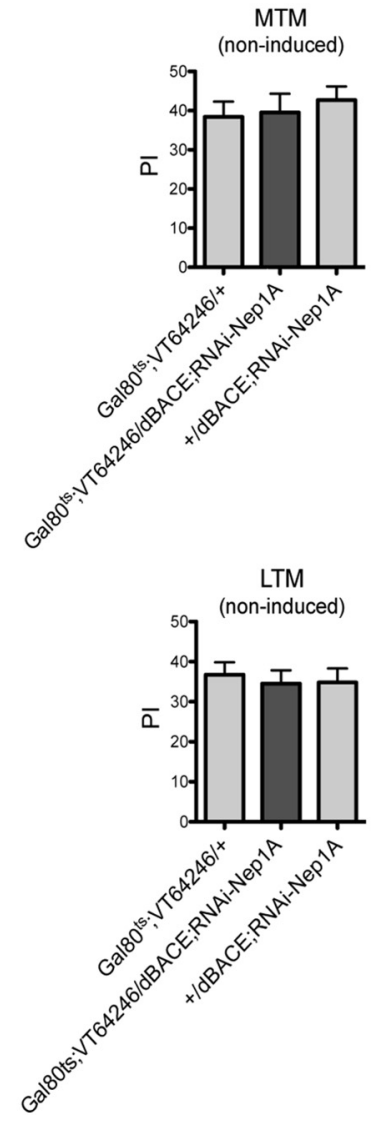

Figure 5. dBACE overexpression aggravates MTM and LTM defects caused by Nep1 knockdown in adult DPM neurons. $A, \mathrm{dBACE}$ overexpression in adult DPM neurons does not alter MTM $\left(F_{(2,35)}=0.0788, p=0.9244, n=12\right)$ or $\operatorname{LTM}\left(F_{(2,36)}=0.0072, p=0.9928, n \geq 11\right)$. $B, \mathrm{dBACE}$ overexpression in DPM neurons exacerbates the MTM deficit cause by Nep1 knockdown $\left(F_{(4,42)}=14.39, p<0.0001, n \geq 8\right.$, post hoc Newman-Keuls test, ${ }^{*} p<0.05$, Gal80 $0^{t 5}$; VT64246/RNAi-Nep1A versus Gal80 ${ }^{\text {ts }}$ VVT64246/+. . ${ }^{*} p<0.05$, Gal80 ; VT64246/RNAi-Nep1A versus +/RNAi-Nep1A. ${ }^{* * *} p<0.001$, Gal80'5; VT64246/dBACE;RNAi-Nep1A versus Gal80 ${ }^{\text {t5 }}$; VT64246/+. ${ }^{* * *} p<0.001$, Gal80's;VT64246/dBACE;RNAi-Nep1A versus +/dBACE;RNAiNep1A. ${ }^{* *} p<0.01$, Gal80 ${ }^{t 5}$;VT64246/dBACE;RNAi-Nep1A versus Gal80 ${ }^{t 5}$;VT64246/RNAiNep1A). In the absence of induction, all genotypes exhibit normal MTM scores $\left(F_{(4,49)}=0.3999\right.$, $p=0.8077, n=10)$. C, dBACE overexpression in DPM neurons exacerbates the LTM deficit caused by Nep1 knockdown $\left(F_{(4,66)}=15.06, p<0.0001, n \geq 13\right.$, post hoc Newman-Keuls test, ${ }^{* * *} p<0.001$, Gal80 ${ }^{\text {ts }}$ VVT64246/RNAi-Nep1A versus Gal80 ${ }^{\text {t5 }}$ VTT64246/+. . ${ }^{* * *} p<0.001$,

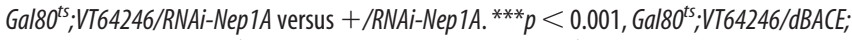

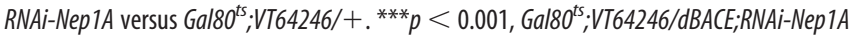
versus +/dBACE;RNAi-Nep1A. ${ }^{*} p<0.05$, Gal80 $0^{t 5} ;$ VT64246/dBACE;RNAi-Nep1A versus Gal80 ${ }^{\text {ts }}$; VT64246/RNAi-Nep1A). In the absence of induction, all genotypes exhibit normal LTM scores $\left(F_{(4,51)}=0.1327, p=0.9696, n \geq 10\right)$.

Table 5. Shock reactivity and olfactory acuity of flies expressing dBACE and RNAi-Nep1A in adult DPM neurons ${ }^{a}$

\begin{tabular}{|c|c|c|c|}
\hline \multirow[b]{2}{*}{ Genotype } & \multirow[b]{2}{*}{ Shock reactivity } & \multicolumn{2}{|l|}{ Olfactory acuity } \\
\hline & & Octanol & Methylcyclohexano \\
\hline Gal80 ${ }^{\text {ts }} ;$ VT64246/+ & $80.40 \pm 4.425$ & $68.80 \pm 5.705$ & $65.10 \pm 4.233$ \\
\hline Gal80'; $;$ VT64246/dBACE;RNAi-Nep1A & $78.40 \pm 3.219$ & $68.90 \pm 5.248$ & $64.00 \pm 5.134$ \\
\hline$+/ d B A C E ; R N A i-N e p 1 A$ & $80.20 \pm 4.828$ & $65.10 \pm 2.799$ & $70.70 \pm 3.448$ \\
\hline
\end{tabular}

${ }^{a}$ Data are mean \pm SEM. After 3 d of induction, neither shock reactivity $\left(F_{(44,4)}=0.3371, p=0.8515, n \geq 8\right)$ nor olfactory acuity for octanol $\left(F_{(4,47)}=0.3231, p=0.8610, n \geq 8\right)$ and methylcyclohexanol $\left(F_{(4,47)}=0.5304, p=\right.$ $0.7140, n \geq 8)$ is impaired in flies expressing dBACE and RNAi-Nep1A under the control of the Gal $80^{t 5}$, VT64246 driver.

Nep1 overexpression in adult DPM neurons rescues the LTM defect caused by $\mathrm{dA} \boldsymbol{\beta}$ expression

We next examined the Nep1-dA $\beta$ interaction in LTM formation. Like expression in $\mathrm{KC}, \mathrm{dA} \beta$ expression in DPM neurons caused a strong LTM defect (Fig. 3A). In the absence of induction, no LTM defect was observed (Fig. 3A). We tested the sensory-motor capacities of $G a l 80^{t s} ;$ VT64246/dA $\beta$ flies, and found that they displayed wild-type shock reactivity and olfactory acuity (Table 3 ). We conclude that, like expression in the $\mathrm{MB}, \mathrm{dA} \beta$ expression in adult DPM neurons induces an LTM deficit. We went on to determine whether Nep1 overexpression could overcome the negative effect of $\mathrm{dA} \beta$ expression on LTM. We observed that Gal80 ${ }^{\text {ts }}$ :VT64246/Nep1 $1^{\text {EY21255 }}$ flies overexpressing Nep1 in adult DPM neurons showed normal LTM (Fig. 3A). Strikingly, flies that overexpressed Nep1 in addition to $\mathrm{dA} \beta$ in adult DPM neurons showed wild-type LTM (Fig. $3 A$ ), suggesting that Nep1 enzyme could degrade $\mathrm{dA} \beta$. We reasoned that the presence of two UAS-GAL4 could result in the decreased expression of each of them caused by GAL4 dilution. Thus, to check that the rescued phenotype observed was not caused by a decrease in $\mathrm{dA} \beta$ expression, we performed qPCR experiments to measure dA $\beta$ mRNA level in Gal80 ${ }^{t s}$; VT64246/dA $\beta$ and Gal80 $^{t s} ; V_{T} 64246 / d A \beta$; $N e p 1^{E Y 21255}$ fly heads. We observed that $\mathrm{dA} \beta$ expression was not decreased by the presence of Nep1 $1^{E Y 21255}$ (Fig. 3B). We thus conclude that, in DPM neurons, Nep1 overexpression rescues the LTM deficit caused by dA $\beta$ expression.

Finally, we examined whether the capacity of Nep1 overexpression to overcome dA $\beta$-induced LTM defect was mediated by its catalytic activity. To this end, we generated a Nep1 form with a mutation in its catalytic site (Devault et al., 1988). To verify the expression level of this mutated Nep1 protein (Nep1 $\left.{ }^{\text {mut }}\right)$, we performed qPCR experiments with oligonucleotides that amplify Nep1 both wild-type and mutant sequences. We observed that Nep1 mRNA levels were increased 5.7-fold in elav/Nep1 $1^{\text {mut }}$ fly heads compared with the elav/+ control, showing efficient Nep1 1 mut expression (Fig. $3 C$ ). Nep $1^{\text {mut }}$ expression in adult DPM neurons did not affect LTM (Fig. 3D). Flies expressing both $\mathrm{dA} \beta$ and Nep $1{ }^{\text {mut }}$ showed LTM scores similar to that of flies expressing only dA $\beta$ (Fig. $3 E$ ). Thus, unlike wild-type Nep1 overexpression, that of Nep $1^{\text {mut }}$ does not rescue the LTM defect caused by $\mathrm{dA} \beta$ expression in adult DPM neurons, indicating that the LTM rescue previously observed depends on Nep1 catalytic activity.

\section{APPL is required in adult DPM neurons for both MTM and LTM}

As we evidenced a functional interaction between ectopic $\mathrm{dA} \beta$ and Nep1 activity in adult DPM neurons, we next investigated whether DPM neurons could physiologically express the amyloid peptide. Because APPL is highly expressed in the MB, it could reveal difficult to determine with immunohistochemistry experiments staining corresponding to DPM neuritis in addition to MB 
A $\underset{\text { (induced) }}{\text { MTM }}$

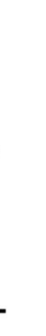

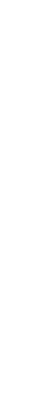
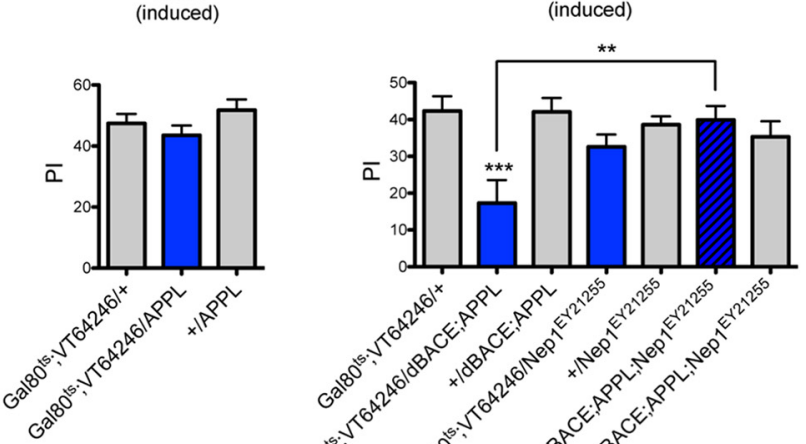

B
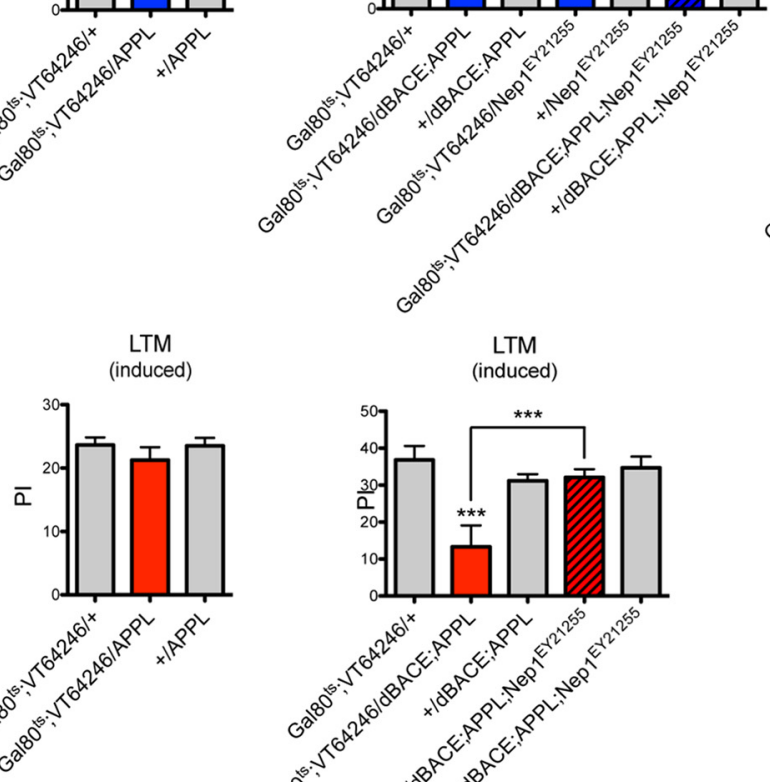

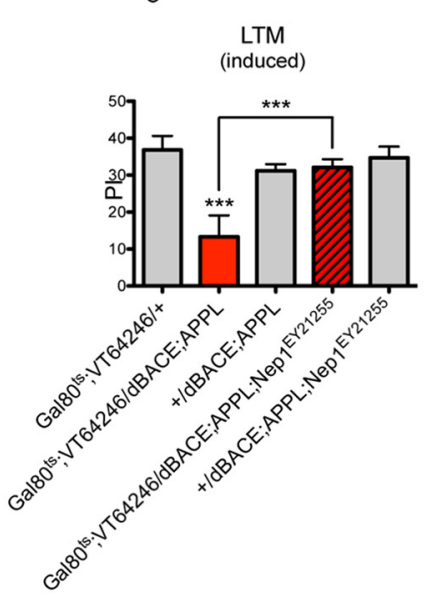

C
App/mRNA

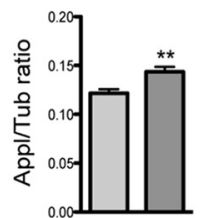

Gal80 $0^{\text {ts }} ; \mathrm{VT} 64246 /+$

$\square$ Gal80 $0^{\text {ts }} ;$ VT64246/dBACE;APPL

D App/mRNA

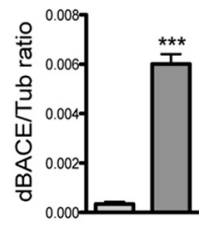

MTM (non-induced) lobes. Instead, we asked whether APPL expression, if any, was required for memory in DPM neurons. We used two nonoverlapping RNAi constructs (RNAi-108312, Bourdet et al., 2015a; RNAi-42673, Goguel et al., 2011) to specifically inhibit APPL expression in adult DPM neurons. Interestingly, Gal80 $0^{t s}$;VT64246/RNAi-42673 and Gal80 $^{t s}$;VT64246/RNAi-108312 flies displayed both mutant MTM (Fig. 4A) and mutant LTM (Fig. 4B). Noninduced flies displayed normal MTM (Fig. 4C) and LTM scores (Fig. 4D), showing that the deficits were specifically caused by induction of APPL RNAi in adult DPM neu-

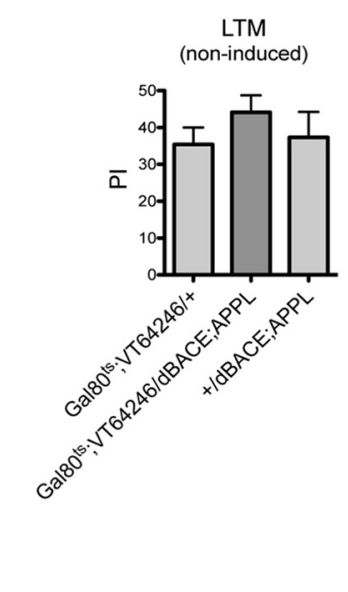

dBACE MRNA

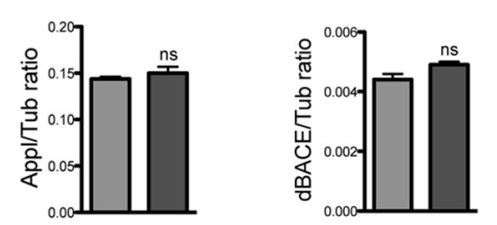

Gal80"s; ;VT64246/dBACE;APPL

Gal80 ${ }^{\text {ts. }} ;$ VT64246/dBACE;APPL;Nep1 ${ }^{\text {EY21255 }}$

\section{E}

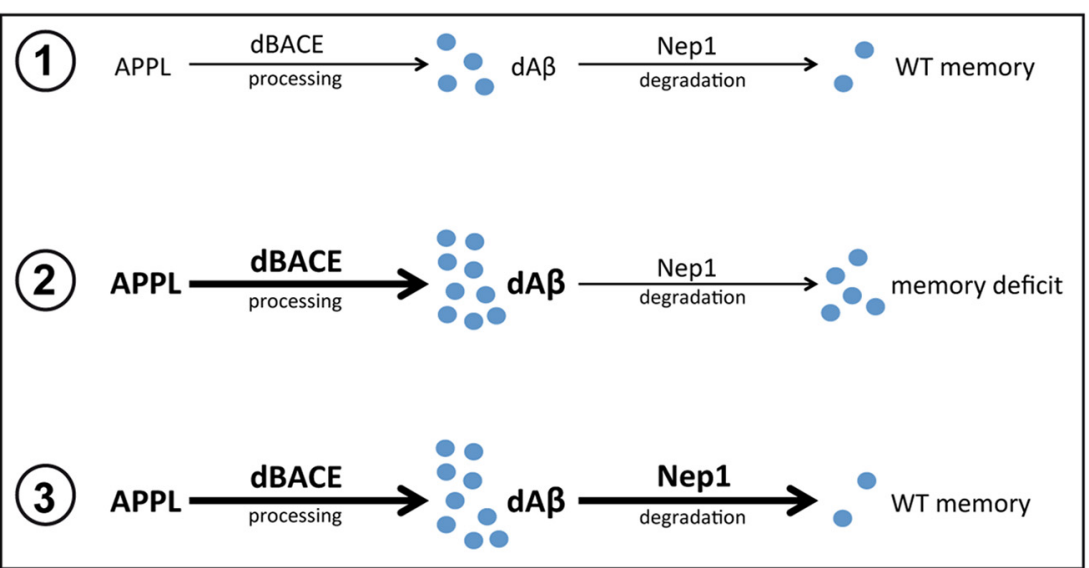

Figure 6. Nep1 overexpression rescues the memory deficit caused by APPL and dBACE coexpression in adult DPM neurons. $A$, Nep1 overexpression rescues the MTM deficit caused by APPL and dBACE coexpression in adult DPM neurons. APPL overexpression in DPM neurons does not alter MTM $\left(F_{(2,35)}=1.575, p=0.2222, n=12\right)$. Flies coexpressing APPL and dBACE in DPM neurons present an MTM defect $\left(F_{(6,70)}=4.559, p=0.0007, n \geq 10\right.$, post hoc Newman-Keuls test, ${ }^{* * *} p<0.001$, Gal80 $;$; VT64246/
dBACE;APPL versus Gal80 ${ }^{\text {ts }} ;$ VT64246/+. ${ }^{* * *} p<0.001$ Gal80 $0^{\text {ts }} ;$ VT64246/dBACE; $A P P L$ versus $\left.+/ d B A C E ; A P P L\right)$. Flies overexpressing Nep1 exhibit normal MTM ( $p>0.05$, Gal $80^{\text {ts }}$; VT64246/Nep $1^{\text {EY21255 }}$ versus Gal80's.VT64246/+. $p>0.05$,

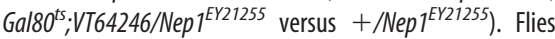
coexpressing dBACE, APPL, and Nep1 present wild-type MTM ( $p>0.05$, Gal80 ${ }^{\text {ts }} ;$ VTT64246/dBACE;APPL;Nep ${ }^{\text {EY21255 }}{ }^{\text {versus }}$

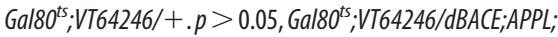
Nep1 ${ }^{\text {EY21255 }}$ versus +/dBACE;APPL;Nep1 EY21255 $* * * 0.01^{*}<$

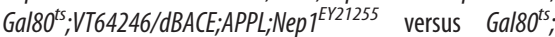
VT64246/dBACE;APPL). In the absence of induction, all genotypes exhibit normal MTM scores $\left(F_{(2,29)}=0.7477, p=\right.$ $0.4830, n=10) \cdot \boldsymbol{B}$, Nep1 overexpression rescues the LTM deficit caused by APPL and dBACE coexpression in adult DPM neurons. APPL overexpression in DPM neurons does not alter LTM $\left(F_{(2,23)}=0.7440, p=0.4873, n=8\right)$. Flies coexpressing APPL and dBACE in DPM neurons present an LTM defect $F_{(6,69)}=7.299$, $p<0.0001, n=10$, post hoc Newman-Keuls test, ${ }^{* * *} p<0.001$, Gal80 $0^{\text {ts }}$,VT64246/dBACE;APPL versus Gal80 ${ }^{\text {t5 }}$; VT64246/+. ${ }^{* * *} p<0.001$, Gal80 ${ }^{\text {ts; }}$;TT64246/dBACE;APPL versus +/dBACE;APPL). Flies coexpressing $\mathrm{dBACE}, \mathrm{APPL}$, and Nep1 present wild-type LTM ( $p>0.05$, Gal80 ${ }^{\text {ts}}$;VT64246/ dBACE;APPL;Nep1 $1^{\text {EY21255 }}$ versus Gal80 $;$ it VT64246/+. $p>0.05$, Gal80 $0^{\text {ts }} ;$ VT64246/dBACE;APPL;Nep1 ${ }^{\text {EY21255 }}$ versus $+/$ dBACE;APPL;Nep1 $1^{\text {EY21255. }}{ }^{* * *} p<0.001$, Gal80 $;$;VT64246/ dBACE;APPL;Nep1 $1^{\text {EY21255 }}$ versus Gal80's $;$ VT64246/dBACE; $A P P L)$. In the absence of induction, all genotypes exhibit normal LTM scores $\left(F_{(2,29)}=0.6927, p=0.5089, n=10\right)$. $C$, $D, q P C R$ experiments. Total RNA was extracted from Gal $80^{t 5}$,

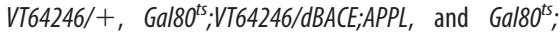

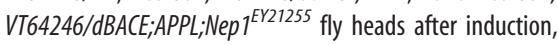
and further reverse-transcribed with oligo(dT) primers. Resulting CDNA was quantified using Tub expression as a reference. Results are shown as ratios to the reference. $\boldsymbol{C}$, Analysis of APPL and dBACE overexpression driven by Gal $80^{\text {t5 }} ;$ VT64246 (Appl: unpaired $t$ test, $t_{(18)}=3.328,{ }^{* *} p=0.0037, n=10$ (10 values from five independent RNA extractions); $d B A C E$ : unpaired $t$ test, $t_{10}=13.83,{ }^{* * *} p<0.0001, n=6$ ( 6 values from three independent RNA extractions)). $D, A p p l$ and $d B A C E$ mRNA expression is not modified by the presence of $\mathrm{Nep}^{\mathrm{EY} 21255}$. (Appl: unpaired $t$ test, $t_{(10)}=0.08343, p=$ $0.4236, n=6(6$ values from three independent RNA extractions); $d B A\left(E\right.$ : unpaired $t$ test, $t_{(6)}=2.319, p=0.0595, n=$ 4 (4 values from two independent RNA extractions)). $E$, Schematic interpretation. $\boldsymbol{E} \mathbf{1}$, In a wild-type context, $\mathrm{dA} \beta$ is degraded by Nep1 to ensure wild-type memory. E2, APPL and $d B A C E$ co-overexpression leads to an increased level of $d A \beta$ that is detrimental to memory formation. $\mathbf{E}$, The memory defect caused by $d A \beta$ overproduction is overcome by an increase in its degradation by Nep1. Blue circles represent $d A \beta$. 
rons. Next, we analyzed learning and observed that RNAi-APPL induced flies showed normal learning performance (Fig. 4E). We checked that induced flies showed normal shock reactivity and normal olfactory acuity to each odor after electric shock exposure (Table 4). We conclude that, in addition to expression in the MB, APPL expression in DPM neurons is required for both MTM and LTM processes. APPL being expressed in DPM neurons, dA $\beta$ may possibly be produced physiologically by adult DPM neurons.

\section{dBACE overexpression aggravates MTM and LTM defects caused by Nep1 knockdown in adult DPM neurons}

We next asked whether overexpression of endogenous $\mathrm{dA} \beta$ impaired memory. The first enzyme responsible for $\mathrm{dA} \beta$ synthesis is the dBACE rate-limiting enzyme (Carmine-Simmen et al., 2009). Using an UAS-dBACE construct that encodes the fly $\beta$-secretase (Carmine-Simmen et al., 2009), we analyzed the effect on memory of dBACE overexpression in adult DPM neurons. After induction, Gal80 ${ }^{t s}$;VT64246/dBACE flies showed both normal MTM and normal LTM (Fig. 5A). If dBACE overexpression results in $\mathrm{dA} \beta$ overproduction, $\mathrm{dA} \beta$ level remains insufficient to disrupt memory. We reasoned that, if Nep1 can degrade endogenous $A \beta$ peptide, Nep1 knockdown should cause a further increase in $\mathrm{dA} \beta$ level that could thus reach a level where it could impair memory. Interestingly, flies expressing both RNAi-Nep1A and ABACE in DPM neurons showed an MTM deficit significantly higher than that of flies expressing only RNAi-Nep1A (Fig. 5B). Noninduced Gal80 ${ }^{t s}$; VT64246/dBACE;RNAi-Nep1A flies displayed normal MTM scores (Fig. 5B). Similar results were observed for LTM: flies expressing both RNAi-Nep1A and dBACE in DPM neurons showed a significantly higher LTM deficit than flies expressing only RNAi-Nep1A, whereas in the absence of GAL4 induction, these flies showed normal scores (Fig. 5C). We verified that induced flies showed normal response to electric shock exposure and normal olfactory acuity (Table 5 ). Together, the data reveal a functional interaction between $\mathrm{dBACE}$ and Nep1, suggesting that dBACE overexpression produces a substrate for Nep1. On Nep1 knockdown, an accumulation of this substrate, presumably dA $\beta$, impairs memory.

Nep1 overexpression rescues the LTM deficit caused by APPL and $\mathrm{ABACE}$ coexpression in adult DPM neurons

It has been shown that $\mathrm{dBACE}$ constitutive neuronal coexpression with APPL generates numerous amyloid deposits in old flies (Carmine-Simmen et al., 2009). As we observed that dBACE overexpression alone did not impair memory, we analyzed dBACE coexpression with APPL. First, we assessed APPL overexpression alone. Like dBACE, APPL overexpression driven in adult DPM neurons did not impact MTM (Fig. 6A). By contrast, flies overexpressing both APPL and dBACE showed decreased MTM scores compared with control flies (Fig. 6A). In the absence of GAL4 induction, these flies showed normal MTM (Fig. 6A). We verified that induced Gal80 ${ }^{t s}$;VT64246/APPL; $d B A C E$ flies displayed normal responses to the conditioning stimuli (Table 6). In conclusion, while neither APPL nor dBACE overexpression alone impacts MTM, concomitant overexpression does, and this effect is very likely caused by an overproduction of $\mathrm{dA} \beta$. We further observed that flies overexpressing Nep1 in addition to APPL and dBACE showed normal MTM (Fig. 6A), indicating that Nep1 overexpression rescues the MTM deficit generated by APPL and dBACE coexpression. We conclude that Nep1 acts in the same pathway as APPL and dBACE.
Table 6. Shock reactivity and olfactory acuity of flies expressing dBACE and APPL in adult DPM neurons ${ }^{a}$

\begin{tabular}{|c|c|c|c|}
\hline \multirow[b]{2}{*}{ Genotype } & \multirow[b]{2}{*}{ Shock reactivity } & \multicolumn{2}{|l|}{ Olfactory acuity } \\
\hline & & Octanol & Methylcyclohexanol \\
\hline Gal80 $;$ tVT64246/+ & $72.70 \pm 6.756$ & $51.20 \pm 2.851$ & $55.10 \pm 1.798$ \\
\hline Gal80 ${ }^{5} ;$ VT64246/dBACE;APPL & $81.78 \pm 5.325$ & $57.00 \pm 3.864$ & $65.30 \pm 8.215$ \\
\hline$+/ d B A C E ; A P P L$ & $69.00 \pm 4.415$ & $56.70 \pm 6.136$ & $58.60 \pm 5.431$ \\
\hline
\end{tabular}

${ }^{a}$ Data are mean \pm SEM. After 3 d of induction, neither shock reactivity $\left(F_{(2,29)}=0.0684, p=0.9341, n=10\right)$ nor olfactory acuity for octanol $\left(F_{(2,29)}=0.2071, p=0.8142, n=10\right)$ and methylcyclohexanol $\left(F_{(2,29)}=0.6896, p=\right.$ $0.5104, n=10)$ is impaired in flies expressing dBACE and APPL under the control of the Gal $80^{t 5} ; V T 64246$ driver.

We next analyzed LTM. Like dBACE, APPL overexpression in adult DPM neurons had no impact on LTM (Fig. 6B). In sharp contrast, APPL and dBACE coexpression caused an LTM deficit that was not observed in the absence of induction (Fig. 6B). Strikingly, concomitant overexpression of Nep1 resulted in normal LTM (Fig. 6B).

We then checked that flies coexpressing APPL, dBACE, and Nep1 expressed APPL and dBACE at similar levels to flies coexpressing only APPL and ABACE. We first examined whether APPL and dBACE overexpression could be assessed by qPCR experiments driven on cDNA synthesized from Gal80 $^{\text {ts }}$;VT64246/ $A P P L ; d B A C E$ fly heads RNA. We observed a significant increase in APPL level in Gal80 ${ }^{t s}$;VT64246/APPL; dBACE fly heads compared with that of the control (Fig. $6 C$ ). In addition, we observed a substantial increase in dBACE expression in Gal80 $^{\text {ts }}$;VT64246/ $A P P L ; A B A C E$ flies compared with the control (Fig. 6C). We next observed that flies coexpressing APPL, dBACE, and Nep1 did not express less APPL, or less $\mathrm{ABACE}$, than flies coexpressing only APPL and dBACE (Fig. 6D).

In conclusion, the data show that the negative effect on MTM and LTM of APPL and ABACE coexpression is rescued by Nep1 overexpression (Fig. 6E).

\section{Discussion}

We showed previously that Nep1 is required in KC and DPM neurons for MTM and LTM, revealing that one or several neuropeptides need to be degraded for memory formation. Here we report that, in adult DPM neurons, Nep1 inhibition makes dA $\beta$ expression detrimental to both MTM and LTM. Conversely, Nep 1 overexpression rescues $\mathrm{dA} \beta$-induced memory defects. Together, the data strongly suggest that Nep1 expressed in DPM neurons degrades $\mathrm{dA} \beta$, raising the possibility that $\mathrm{dA} \beta$ is a Nep 1 physiological substrate for memory processes.

Drosophila is currently used to model $\mathrm{AD}$, in particular $\mathrm{A} \beta$ induced toxicity (Iijima et al., 2004; Fang et al., 2012; Lin et al., 2014; Niccoli et al., 2016; Sofola-Adesakin et al., 2016). Transgenic flies overexpressing human $\mathrm{A} \beta 42$ in the eyes display doseand age-dependent phenotypes that are alleviated by Nep2 upregulation (Finelli et al., 2004; Cao et al., 2008). One of the limits of these models is that ectopic human $A \beta$ is expressed constitutively, and is therefore highly toxic, probably by disrupting normal development and/or cell physiology. Here we performed an inducible analysis of $\mathrm{dA} \beta$ expression in young flies, thereby providing a more physiological model. We observe identical memory phenotypes when $\mathrm{dA} \beta$ is expressed either in $\mathrm{KC}$ or in DPM neurons of young flies: MTM is normal, whereas LTM is disrupted. One hypothesis is that $\mathrm{dA} \beta$ expression alters general functional features of the neuron biology and that its toxicity is therefore unspecific to memory. However, $\mathrm{dA} \beta$-expressing flies show normal reactivity to the conditioning stimuli used and display normal MTM, suggesting that such $\mathrm{dA} \beta$ production might instead interfere with specific mechanisms in play for memory 
formation. One hypothesis is that $\mathrm{dA} \beta$ impacts mechanisms specific to LTM. Alternatively, $\mathrm{dA} \beta$ expression level may be an important feature for both MTM and LTM: $\mathrm{dA} \beta$ levels reached in our experiments may alter LTM but may not be sufficient to alter MTM. We favor this latter hypothesis as APPL and ABACE coexpression disrupts both MTM and LTM. Indeed, as overexpression of APPL or dBACE alone does not affect memory, we conclude that memory defects observed on coexpression result from APPL processing by $\mathrm{dBACE}$, and thus very likely from $\mathrm{dA} \beta$ production.

In addition to $\mathrm{A} \beta$, $\mathrm{APP}$ complex processing leads to numerous biologically active fragments that are secreted, membranous or intracellular (O'Brien and Wong, 2011; Zheng and Koo, 2011). We previously showed that a secreted APPL and a noncleaved APPL form were involved in MTM in adult $\alpha / \beta \mathrm{KC}$ (Bourdet et al., 2015a). We now show that APPL expression is also required in DPM neurons. Interestingly, APPL conditional silencing specifically in KC or in DPM neurons leads to similar phenotypes: MTM and LTM are impaired, whereas learning remains unaffected. These data highlight the close relationship between DPM neurons and $\mathrm{KC}$, a circuit thought to stabilize memories (Keene et al., 2004; Pitman et al., 2011), and suggest that APPL plays similar roles in both neuronal structures. In mammals, APP is expressed at presynaptic and postsynaptic sites (Yamazaki et al., 1995; Back et al., 2007; Hoe et al., 2009), and APP/APP transdimers have been shown to play a role in synaptic connectivity (Wang et al., 2009). It is therefore possible that APPL/APPL transdimers play a role at KC/DPM synapses. Another hypothesis is that an APPL fragment secreted from one cell type is a ligand for APPL located at the membrane of the other cell type, consistent with reports suggesting that APPL may function as a receptor (Cassar and Kretzschmar, 2016).

Nep peptidases constitute the main $A \beta$-degrading enzymes in mammals. They have also been implicated in diverse pathologies, but their substrates have remained poorly described. In Drosophila, a nonidentified neprilysin-like neuropeptidase was shown to play a role in the regulation of the pigment-dispersing factor signaling within circadian neural circuits (Isaac et al., 2007). More recently, Nep4 was shown to be involved in the expression of a number of insulin-like peptides (Hallier et al., 2016). Our data show that an increased expression of $\mathrm{dA} \beta$ is detrimental to memory. In a context where $\mathrm{dA} \beta$ level is below a deleterious threshold, knocking down Nep1 is sufficient to raise this level above the threshold, thus leading to memory deficits. Conversely, if $\mathrm{dA} \beta$ level is above a deleterious threshold, concomitant overexpression of Nep1 restores wild-type memory. Although a noncatalytic role has been described for Nep4 intracellular domain (Panz et al., 2012), Nep1 catalytic activity is required to observe the rescue of the $\mathrm{dA} \beta$ induced memory deficit, indicating that Nep1 degrades $\mathrm{dA} \beta$. This conclusion is further supported by Western blot experiments showing that Nep1 inhibition results in an increase in $\mathrm{dA} \beta$ levels. Together, our data strongly suggest that Nep1, a membrane proteinase whose active site faces the extracellular compartment, cleaves and inactivates $\mathrm{dA} \beta$ in the extracellular space, consistent with the consensus that Nep function is to turn off neuropeptide signals at the synapse (Turner, 2003).

A functional interaction between $\mathrm{Nep} 1$ and $\mathrm{dA} \beta$ is evidenced when modulation of their expression is achieved in DPM neurons, and not in KC. One hypothesis is that Nep1 is not expressed at the synapses where $\mathrm{dA} \beta$ is secreted in $\alpha / \beta \mathrm{KC}$. Another possibility is that Nep 1 is differently regulated in $\alpha / \beta \mathrm{KC}$ and DPM neurons, leading to distinct specificity: Nep peptidases exhibit high substrate variability and are thus known to target numerous peptides (Turner et al., 2001; Nalivaeva et al., 2012). A recent study suggested that Nep4 activity in the CNS affected different neuropeptide regulatory systems from the corresponding musclebound activity (Hallier et al., 2016). Thus, Nep1 expressed at DPM membranes could target $\mathrm{d} A \beta$, and a distinct peptide when expressed in KC.

Learning and memory are associated with activity-dependent functional plasticity and changes in the structure and number of synapses (Korte and Schmitz, 2016). In AD patients, synaptic dysfunction has been closely correlated with cognitive decline (Querfurth and LaFerla, 2010). A large body of evidence points to a pathological role of $\mathrm{A} \beta$, particularly as a primary cause of synaptic failure (Hardy and Selkoe, 2002; O'Brien and Wong, 2011). Importantly, $A \beta$ is present in the CSF of healthy individuals, although at much lower concentrations than its neurotoxic concentrations, suggesting the possibility of a physiological role for $\mathrm{A} \beta$ (Fedele et al., 2015). In primary cultures of neurons, immunodepletion of endogenous $A \beta$ causes neuronal cell death, a phenomenon rescued by addition of physiological picomolar levels of $A \beta$ peptides (Plant et al., 2003). Furthermore, several reports have shown that, at very low physiological concentrations, $\mathrm{A} \beta$ modulates synaptic strength (Kamenetz et al., 2003; Abramov et al., 2009). Puzzo et al. (2008) reported that picomolar amounts of $\mathrm{A} \beta$ were able to enhance LTP and hippocampal-dependent memory in mice, whereas nanomolar concentrations of the peptide gave opposite results. Several additional studies confirmed the role of $A \beta$ at low concentrations in synaptic plasticity and memory (Garcia-Osta and Alberini, 2009; Morley et al., 2010; Puzzo et al., 2011), suggesting that $A \beta$ physiologically produced in the healthy brain during neuronal activity is needed for memory processes. Thus, $\mathrm{A} \beta$ appears to be a modulator of synaptic activity whose concentration needs to be strictly regulated: at the level of its production, degradation, or trafficking. We report here in Drosophila that memory disruption caused by an increased synthesis of $\mathrm{dA} \beta$ is rescued by Nep 1 overexpression, raising the possibility that Nep-dependent degradation of $\mathrm{dA} \beta$ plays a physiological role in memory. A deficit in $A \beta$ degradation would thus trigger memory deficits, the first cognitive signs of AD. Such mechanisms are consistent with evidence showing that late-onset $\mathrm{AD}$ is associated with impaired clearance of $A \beta$ (Mawuenyega et al., 2010 ), and that AD brains show decreased levels of Nep expression and activity (Yasojima et al., 2001; Caccamo et al., 2005; Wang et al., 2010; Zhou et al., 2013).

\section{References}

Abramov E, Dolev I, Fogel H, Ciccotosto GD, Ruff E, Slutsky I (2009) Amyloid- $\beta$ as a positive endogenous regulator of release probability at hippocampal synapses. Nat Neurosci 12:1567-1576. CrossRef Medline

Back S, Haas P, Tschäpe JA, Gruebl T, Kirsch J, Müller U, Beyreuther K, Kins $S$ (2007) $\beta$-Amyloid precursor protein can be transported independent of any sorting signal to the axonal and dendritic compartment. J Neurosci Res 85:2580-2590. CrossRef Medline

Bellen HJ, Levis RW, Liao G, He Y, Carlson JW, Tsang G, Evans-Holm M, Hiesinger PR, Schulze KL, Rubin GM, Hoskins RA, Spradling AC (2004) The BDGP gene disruption project: single transposon insertions associated with 40\% of Drosophila genes. Genetics 167:761-781. CrossRef Medline

Boulianne GL, Livne-Bar I, Humphreys JM, Liang Y, Lin C, Rogaev E, St George-Hyslop P (1997) Cloning and characterization of the Drosophila presenilin homologue. Neuroreport 8:1025-1029. CrossRef Medline

Bourdet I, Preat T, Goguel V (2015a) The full-length form of the Drosophila amyloid precursor protein is involved in memory formation. J Neurosci 35:1043-1051. CrossRef Medline

Bourdet I, Lampin-Saint-Amaux A, Preat T, Goguel V (2015b) Amyloid- $\beta$ peptide exacerbates the memory deficit caused by amyloid precursor protein loss-of-function in Drosophila. PLoS One 10:e0135741-14. CrossRef Medline 
Bouzaiane E, Trannoy S, Scheunemann L, Plaçais PY, Preat T (2015) Two independent mushroom body output circuits retrieve the six discrete components of Drosophila aversive memory. Cell Rep 11:1280-1292. CrossRef Medline

Brand AH, Perrimon N (1993) Targeted gene expression as a means of altering cell fates and generating dominant phenotypes. Development 118: 401-415. Medline

Burnouf S, Gorsky MK, Dols J, Grönke S, Partridge L (2015) A $\beta 43$ is neurotoxic and primes aggregation of $A \beta 40$ in vivo. Acta Neuropathol 130: 35-47. CrossRef Medline

Caccamo A, Oddo S, Sugarman MC, Akbari Y, LaFerla FM (2005) Age- and region-dependent alterations in $\mathrm{A} \beta$-degrading enzymes: implications for A $\beta$-induced disorders. Neurobiol Aging 26:645-654. CrossRef Medline

Cao W, Song HJ, Gangi T, Kelkar A, Antani I, Garza D, Konsolaki M (2008) Identification of novel genes that modify phenotypes induced by Alzheimer's $\beta$-amyloid overexpression in Drosophila. Genetics 178:1457-1471. CrossRef Medline

Carmine-Simmen K, Proctor T, Tschäpe J, Poeck B, Triphan T, Strauss R, Kretzschmar D (2009) Neurotoxic effects induced by the Drosophila amyloid- $\beta$ peptide suggest a conserved toxic function. Neurobiol Dis 33:274-281. CrossRef Medline

Cassar M, Kretzschmar D (2016) Analysis of amyloid precursor protein function in Drosophila melanogaster. Front Mol Neurosci 9:17-19. CrossRef Medline

Cole SL, Vassar R (2007) The Alzheimer's disease $\beta$-secretase enzyme, BACE1. Mol Neurodegener 2:22-25. CrossRef Medline

Crittenden JR, Skoulakis EM, Han KA, Kalderon D, Davis RL (1998) Tripartite mushroom body architecture revealed by antigenic markers. Learn Mem 5:38-51. Medline

Devault A, Nault C, Zollinger M, Fournie-Zaluski MC, Roques BP, Crine P, Boileau G (1988) Expression of neutral endopeptidase (enkephalinase) in heterologous COS-1 cells: characterization of the recombinant enzyme and evidence for a glutamic acid residue at the active site. J Biol Chem 263:4033-4040. Medline

Fang L, Duan J, Ran D, Fan Z, Yan Y, Huang N, Gu H, Zhu Y (2012) Amyloid- $\beta$ depresses excitatory cholinergic synaptic transmission in Drosophila. Neurosci Bull 28:585-594. CrossRef Medline

Fedele E, Rivera D, Marengo B, Pronzato MA, Ricciarelli R (2015) Amyloid $\beta$ : walking on the dark side of the moon. Mech Ageing Dev 152:1-4. CrossRef Medline

Finelli A, Kelkar A, Song HJ, Yang H, Konsolaki M (2004) A model for studying Alzheimer's A $\beta 42$-induced toxicity in Drosophila melanogaster. Mol Cell Neurosci 26:365-375. CrossRef Medline

Garcia-Osta A, Alberini CM (2009) Amyloid beta mediates memory formation. Learn Mem 16:267-272. CrossRef Medline

Goguel V, Belair AL, Ayaz D, Lampin-Saint-Amaux A, Scaplehorn N, Hassan BA, Preat T (2011) Drosophila amyloid precursor protein-like is required for long-term memory. J Neurosci 31:1032-1037. CrossRef Medline

Hallier B, Schiemann R, Cordes E, Vitos-Faleato J, Walter S, Heinisch JJ, Malmendal A, Paululat A, Meyer H (2016) Drosophila neprilysins control insulin signaling and food intake via cleavage of regulatory peptides. eLife 5:e19430. CrossRef Medline

Hardy J, Selkoe DJ (2002) The amyloid hypothesis of Alzheimer's disease: progress and problems on the road to therapeutics. Science 297:353-356. CrossRef Medline

Hoe HS, Fu Z, Makarova A, Lee JY, Lu C, Feng L, Pajoohesh-Ganji A, Matsuoka Y, Hyman BT, Ehlers MD, Vicini S, Pak DT, Rebeck GW (2009) The effects of amyloid precursor protein on postsynaptic composition and activity. J Biol Chem 284:8495-8506. CrossRef Medline

Hong CS, Koo EH (1997) Isolation and characterization of Drosophila presenilin homolog. Neuroreport 8:665-668. CrossRef Medline

Hüttenrauch M, Baches S, Gerth J, Bayer TA, Weggen S, Wirths O (2015) Neprilysin deficiency alters the neuropathological and behavioral phenotype in the 5XFAD mouse model of Alzheimer's disease. J Alzheimers Dis 44:1291-1302. CrossRef Medline

Iijima K, Liu HP, Chiang AS, Hearn SA, Konsolaki M, Zhong Y (2004) Dissecting the pathological effects of human $\mathrm{A} \beta 40$ and $\mathrm{A} \beta 42$ in Drosophila: a potential model for Alzheimer's disease. Proc Natl Acad Sci U S A 101: 6623-6628. CrossRef Medline

Isaac RE, Johnson EC, Audsley N, Shirras AD (2007) Metabolic inactivation of the circadian transmitter, pigment dispersing factor (PDF), by neprilysin-like peptidases in Drosophila. J Exp Biol 210:4465-4470. CrossRef Medline

Isabel G, Pascual A, Preat T (2004) Exclusive consolidated memory phases in Drosophila. Science 304:1024-1027. CrossRef Medline

Kamenetz F, Tomita T, Hsieh H, Seabrook G, Borchelt D, Iwatsubo T, Sisodia S, Malinow R (2003) APP processing and synaptic function. Neuron 37:925-937. CrossRef Medline

Keene AC, Stratmann M, Keller A, Perrat PN, Vosshall LB, Waddell S (2004) Diverse odor-conditioned memories require uniquely timed dorsal paired medial neuron output. Neuron 44:521-533. CrossRef Medline

Korte M, Schmitz D (2016) Cellular and system biology of memory: timing, molecules, and beyond. Physiol Rev 96:647-693. CrossRef Medline

Lin JY, Wang WA, Zhang X, Liu HY, Zhao XL, Huang FD (2014) Intraneuronal accumulation of $A \beta 42$ induces age-dependent slowing of neuronal transmission in Drosophila. Neurosci Bull 30:185-190. CrossRef Medline

Luo L, Tully T, White K (1992) Human amyloid precursor protein ameliorates behavioral deficit of flies deleted for Appl gene. Neuron 9:595-605. CrossRef Medline

Mawuenyega KG, Sigurdson W, Ovod V, Munsell L, Kasten T, Morris JC, Yarasheski KE, Bateman RJ (2010) Decreased clearance of CNS betaamyloid in Alzheimer's disease. Science 330:1774. CrossRef Medline

McGuire SE, Le PT, Osborn AJ, Matsumoto K, Davis RL (2003) Spatiotemporal rescue of memory dysfunction in Drosophila. Science 302:17651768. CrossRef Medline

Meyer H, Panz M, Albrecht S, Drechsler M, Wang S, Hüsken M, Lehmacher C, Paululat A (2011) Drosophila metalloproteases in development and differentiation: the role of ADAM proteins and their relatives. Eur J Cell Biol 90:770-778. CrossRef Medline

Morley JE, Farr SA, Banks WA, Johnson SN, Yamada KA, Xu L (2010) A physiological role for amyloid- $\beta$ protein: enhancement of learning and memory. J Alzheimers Dis 19:441-449. CrossRef Medline

Nalivaeva NN, Belyaev ND, Zhuravin IA, Turner AJ (2012) The Alzheimer's amyloid-degrading peptidase, neprilysin: can we control it? Int J Alzheimers Dis 2012:383796. CrossRef Medline

Niccoli T, Cabecinha M, Tillmann A, Kerr F, Wong CT, Cardenes D, Vincent AJ, Bettedi L, Li L, Grönke S, Dols J, Partridge L (2016) Increased glucose transport into neurons rescues A $\beta$ toxicity in Drosophila. Curr Biol 26:2291-2300. CrossRef Medline

O'Brien RJ, Wong PC (2011) Amyloid precursor protein processing and Alzheimer's disease. Annu Rev Neurosci 34:185-204. CrossRef Medline

Panz M, Vitos-Faleato J, Jendretzki A, Heinisch JJ, Paululat A, Meyer H (2012) A novel role for the noncatalytic intracellular domain of Neprilysins in muscle physiology. Biol Cell 104:553-568. CrossRef Medline

Park MH, Lee JK, Choi S, Ahn J, Jin HK, Park JS, Bae JS (2013) Recombinant soluble neprilysin reduces amyloid- $\beta$ accumulation and improves memory impairment in Alzheimer's disease mice. Brain Res 1529:113-124. CrossRef Medline

Pascual A, Preat T (2001) Localization of long-term memory within the Drosophila mushroom body. Science 294:1115-1117. CrossRef Medline

Pitman JL, Huetteroth W, Burke CJ, Krashes MJ, Lai SL, Lee T, Waddell S (2011) A pair of inhibitory neurons are required to sustain labile memory in the Drosophila mushroom body. Curr Biol 21:855-861. CrossRef Medline

Plant LD, Boyle JP, Smith IF, Peers C, Pearson HA (2003) The production of amyloid $\beta$ peptide is a critical requirement for the viability of central neurons. J Neurosci 23:5531-5535. Medline

Poeck B, Strauss R, Kretzschmar D (2012) Analysis of amyloid precursor protein function in Drosophila melanogaster. Exp Brain Res 217:413-421. CrossRef Medline

Poirier R, Wolfer DP, Welzl H, Tracy J, Galsworthy MJ, Nitsch RM, Mohajeri MH (2006) Neuronal neprilysin overexpression is associated with attenuation of $A \beta$-related spatial memory deficit. Neurobiol Dis 24:475-483. CrossRef Medline

Puzzo D, Privitera L, Leznik E, Fà M, Staniszewski A, Palmeri A, Arancio O (2008) Picomolar amyloid- $\beta$ positively modulates synaptic plasticity and memory in hippocampus. J Neurosci 28:14537-14545. CrossRef Medline

Puzzo D, Privitera L, Fà M, Staniszewski A, Hashimoto G, Aziz F, Sakurai M, Ribe EM, Troy CM, Mercken M, Jung SS, Palmeri A, Arancio O (2011) Endogenous amyloid- $\beta$ is necessary for hippocampal synaptic plasticity and memory. Ann Neurol 69:819-830. CrossRef Medline

Querfurth HW, LaFerla FM (2010) Alzheimer's disease. N Engl J Med 362: 329-344. CrossRef Medline 
Reiter LT, Potocki L, Chien S, Gribskov M, Bier E (2001) A systematic analysis of human disease-associated gene sequences in Drosophila melanogaster. Genome Res 11:1114-1125. CrossRef Medline

Rooke J, Pan D, Xu T, Rubin GM (1996) KUZ, a conserved metalloproteasedisintegrin protein with two roles in Drosophila neurogenesis. Science 273:1227-1231. CrossRef Medline

Rosen DR, Martin-Morris L, Luo LQ, White K (1989) A Drosophila gene encoding a protein resembling the human $\beta$-amyloid protein precursor. Proc Natl Acad Sci U S A 86:2478-2482. CrossRef Medline

Sitnik JL, Francis C, Hens K, Huybrechts R, Wolfner MF, Callaerts P (2014) Neprilysins: an evolutionarily conserved family of metalloproteases that play important roles in reproduction in Drosophila. Genetics 196:781797. CrossRef Medline

Sofola-Adesakin O, Khericha M, Snoeren I, Tsuda L, Partridge L (2016) pGluA $\beta$ increases accumulation of $A \beta$ in vivo and exacerbates its toxicity. Acta Neuropathol Commun 4:109. CrossRef Medline

Spencer B, Marr RA, Rockenstein E, Crews L, Adame A, Potkar R, Patrick C, Gage FH, Verma IM, Masliah E (2008) Long-term neprilysin gene transfer is associated with reduced levels of intracellular Abeta and behavioral improvement in APP transgenic mice. BMC Neurosci 9:109-112. CrossRef Medline

Torroja L, Chu H, Kotovsky I, White K (1999) Neuronal overexpression of APPL, the Drosophila homologue of the amyloid precursor protein (APP), disrupts axonal transport. Curr Biol 9:489-492. CrossRef Medline

Tully T, Quinn WG (1985) Classical conditioning and retention in normal and mutant Drosophila melanogaster. J Comp Physiol A 157:263-277. CrossRef Medline

Tully T, Preat T, Boynton SC, Del Vecchio M (1994) Genetic dissection of consolidated memory in Drosophila. Cell 79:35-47. CrossRef Medline

Turner AJ (2003) Exploring the structure and function of zinc metallopeptidases: old enzymes and new discoveries. Biochem Soc Trans 31:723-727. CrossRef Medline
Turner AJ, Isaac RE, Coates D (2001) The neprilysin (NEP) family of zinc metalloendopeptidases: genomics and function. Bioessays 23:261-269. CrossRef Medline

Turner PR, O'Connor K, Tate WP, Abraham WC (2003) Roles of amyloid precursor protein and its fragments in regulating neural activity, plasticity and memory. Prog Neurobiol 70:1-32. CrossRef Medline

Turrel O, Lampin-Saint-Amaux A, Preat T, Goguel V (2016) Drosophila neprilysins are involved in middle-term and long-term memory. J Neurosci 36:9535-9546. CrossRef Medline

Wang S, Wang R, Chen L, Bennett DA, Dickson DW, Wang DS (2010) Expression and functional profiling of neprilysin, insulin-degrading enzyme, and endothelin-converting enzyme in prospectively studied elderly and Alzheimer's brain. J Neurochem 115:47-57. CrossRef Medline

Wang Z, Wang B, Yang L, Guo Q, Aithmitti N, Songyang Z, Zheng H (2009) Presynaptic and postsynaptic interaction of the amyloid precursor protein promotes peripheral and central synaptogenesis. J Neurosci 29: 10788-10801. CrossRef Medline

Yamazaki T, Selkoe DJ, Koo EH (1995) Trafficking of cell surface $\beta$-amyloid precursor protein: retrograde and transcytotic transport in cultured neurons. J Cell Biol 129:431-442. CrossRef Medline

Yang MY, Armstrong JD, Vilinsky I, Strausfeld NJ, Kaiser K (1995) Subdivision of the Drosophila mushroom bodies by enhancer-trap expression patterns. Neuron 15:45-54. CrossRef Medline

Yasojima K, McGeer EG, McGeer PL (2001) Relationship between beta amyloid peptide generating molecules and neprilysin in Alzheimer disease and normal brain. Brain Res 919:115-121. CrossRef Medline

Zheng H, Koo EH (2011) Biology and pathophysiology of the amyloid precursor protein. Mol Neurodegener 6:27. CrossRef Medline

Zhou L, Wei C, Huang W, Bennett DA, Dickson DW, Wang R (2013) Distinct subcellular patterns of neprilysin protein and activity in the brains of Alzheimer's disease patients, transgenic mice and cultured human neuronal cells. Am J Transl Res 5:608-621. Medline 